Western University

Scholarship@Western

Earth Sciences Publications

Earth Sciences Department

2016

\title{
Taxonomy, location of origin, and health status of proboscideans from Western Canada investigated using stable isotope analysis
}

Jessica Z. Metcalfe

The University of Western Ontario

Fred Longstaffe

The University of Western Ontario, flongsta@uwo.ca

Christopher N.Jass

Royal Alberta Museum

Grant D. Zazula

Government of Yukon

Grant Keddie

Royal British Columbia Museum

Follow this and additional works at: https://ir.lib.uwo.ca/earthpub

Part of the Geochemistry Commons, and the Paleontology Commons

Citation of this paper:

Metcalfe, Jessica Z.; Longstaffe, Fred; Jass, Christopher N.; Zazula, Grant D.; and Keddie, Grant, "Taxonomy, location of origin, and health status of proboscideans from Western Canada investigated using stable isotope analysis" (2016). Earth Sciences Publications. 8.

https://ir.lib.uwo.ca/earthpub/8 


\title{
Taxonomy, location of origin, and health status of proboscideans from Western Canada investigated using stable isotope analysis
}

\author{
Running head: Stable isotope analyses of Western Canada proboscideans \\ Jessica Z. Metcalfe ${ }^{a^{*}}$, Fred J. Longstaffe ${ }^{a}$, Christopher N. Jass ${ }^{b}$, Grant D. Zazula ${ }^{c}$, Grant \\ Keddie $^{\text {d }}$ \\ ${ }^{\text {a }}$ Department of Earth Sciences, The University of Western Ontario, London, Ontario, Canada \\ N6A 5B7 \\ ${ }^{\mathrm{b}}$ Quaternary Palaeontology Program, Royal Alberta Museum, 12845 - 102 Avenue, Edmonton, \\ Alberta, Canada T5N 0M6 \\ ${ }^{\mathrm{c}}$ Yukon Palaeontology Program, Department of Tourism \& Culture, Government of Yukon, PO \\ Box 2703, Whitehorse, Yukon, Canada Y1A 2C6 \\ ${ }^{\mathrm{d}}$ Department of Archaeology, Royal British Columbia Museum, 675 Belleville St., Victoria, \\ British Columbia, Canada V8V 1X4 \\ * Corresponding author. Present address: Department of Anthropology, The University of British \\ Columbia, 6303 NW Marine Dr., Vancouver, BC, Canada V6T 1Z1. \\ jess_metcalfe@hotmail.com
}




\begin{abstract}
We investigated the application of stable isotope analysis of proboscidean remains (collagen in bone/dentin/cementum and structural carbonate in enamel bioapatite) for genus-level identification of isolated specimens, assessment of geographic origins, and testing for nutritional stress. Mammoths (Mammuthus sp.) tended to have higher $\delta^{15} \mathrm{~N}_{\mathrm{col}}$ and lower $\delta^{13} \mathrm{C}_{\mathrm{col}}$ than mastodons (Mammut americanum), but differences were not significant in every location. Determining the genus of isolated specimens may be possible for locations and time periods with good isotopic baselines, but environmental changes can confound interpretations. For example, an Alberta proboscidean with a $\delta^{15} \mathrm{~N}_{\mathrm{col}}$ of $+1.4 \%$ (characteristic of mastodons) ultimately proved to be a mammoth. Its surprisingly low nitrogen isotope composition is attributable to the recently deglaciated environment it inhabited. We provided a baseline for isotopic assessment of geographic origins of isolated proboscideans in Western Canada. Bioapatite $\delta^{13} \mathrm{C}_{\mathrm{sc}}$ and $\delta^{18} \mathrm{O}_{\mathrm{sc}}$ can be used to distinguish specimens from Alberta, Klondike, Old Crow, Herschel Island, and further south (e.g., Arizona, Great Lakes). Finally, we found that an Alberta mammoth with morphological evidence of nutritional stress experienced a change in diet, environment, or physiology prior to death, but its isotopic compositions did not suggest a link to hypothesized starvation (catabolism of proteins or reliance on lipids).
\end{abstract}

\title{
Keywords:
}

Isotopes; mammoth; mastodon; collagen; carbonate 


\section{Introduction}

Stable isotope compositions of fossil vertebrate remains can be used to reconstruct the behaviour (e.g., diet, migration), physiology (e.g., starvation) and paleoenvironmental context (e.g., vegetation, temperature, aridity, $\mathrm{pCO}_{2}$, and canopy cover) of extinct organisms (Clementz, 2012; Hatch, 2012; Koch, 1998; Koch et al., 1994; Kohn and Cerling, 2002; West et al., 2006). Stable isotope compositions are also commonly used to identify or verify the origins of various modern substances (e.g., Chesson et al., 2010a, b), and can also be useful for inferring the geographical origins of humans or animals in ancient landscapes (e.g., Dupras and Schwarcz, 2001; Knudson and Price, 2007; White et al., 1998).

In this paper, we explore the use of $\delta^{13} \mathrm{C}$ (collagen and bioapatite), $\delta^{15} \mathrm{~N}$ (collagen), and $\delta^{18} \mathrm{O}$ (structural carbonate in bioapatite) of extinct proboscideans for genus-level identification of isolated remains, determination of location of origin, and investigation of health status, using specimens from Western Canada (Alberta, British Columbia, and Yukon). We ask: (1) Are there consistent differences in the isotopic compositions of mammoths and mastodons in each location? (2) Can skeletal fragments of proboscideans that lack morphologically diagnostic features be assigned to genus (Mammuthus vs. Mammut) based on isotopic compositions? (3) Are there consistent differences in isotopic compositions of proboscidean fossils across geographic locations (Alberta, British Columbia, and Yukon - including Old Crow, Klondike, and Herschel Island), which could allow location-of-origin determination for isolated specimens from museum collections? (4) Do the isotopic compositions of an abnormal mammoth tooth support a hypothesis of nutritional stress prior to death? 
To date, studies that have used stable isotope compositions to investigate proboscidean paleobiology in western Canada have focused on food web and climatic reconstruction (FoxDobbs et al., 2008; Matheus et al., 2003a, b; Schwartz-Narbonne et al., 2015; Szpak et al., 2010) or nursing/weaning behaviour (Metcalfe et al., 2010) within the Yukon Territory. At a fundamental level, our intent is to provide baseline isotopic data for Pleistocene proboscideans from western Canada. All subsequent paleobiological research questions require an understanding of the variation in isotopic compositions within these taxa across time and space.

\section{Mammoth and Mastodon Ecology}

The Mammutidae and Elephantidae diverged at the end of the Oligocene or the beginning of the Miocene, ca. 27-23 Ma (Agenbroad, 2005). Morphologically, the most obvious difference between mastodons (Mammut americanum) and mammoths (Mammuthus spp.) is their dentition, which is adapted to browsing in the former, and grazing in the latter. Mastodon remains are typically associated with relatively wet, forested regions, such as that present in the Great Lakes region during the terminal Pleistocene (Dreimanis, 1967, 1968; Haynes, 1991; McAndrews and Jackson, 1988; Newsom and Mihlbachler, 2006; Saunders, 1996; Yansa and Adams, 2012). Studies of mastodon tooth enamel isotopic compositions, microwear, and gut/fecal contents support a browsing adaptation (Green et al., 2005; Koch et al., 1998; Lepper et al., 1991; MacFadden and Cerling, 1996; Newsom and Mihlbachler, 2006), although mastodon diets did include some grasses (Gobetz and Bozarth, 2001; Koch et al., 1998) and mastodons were able to adapt to significant temporal changes in vegetation within the Great Lakes region (Metcalfe and Longstaffe, 2014). Woolly mammoths (Mammuthus primigenius) were associated with open steppe-tundra environments (Guthrie, 2001; Haynes, 1991) and their southern cousins, the 
Columbian mammoths (Mammuthus columbi), were most common in temperate grasslands (Agenbroad, 2005). Mammoths were predominantly grazers, as shown by their tooth enamel isotopic compositions, gut contents, fecal remains, and phyoliths in dental calculus, though they also consumed woody plants, mosses, and a variety of shrubs and forbs (Cummings and Albert, 2007; Feranec, 2004; Guthrie, 2001; Haynes, 1991; Hoppe, 2004; Koch et al., 1998; Mead et al., 1986; van Geel et al., 2008). Both mammoths and mastodons were widespread in North America during the late Pleistocene ( $\sim 125$ to $10 \mathrm{ka})$, occupying most of the regions south of the continental glaciers, as well as Beringia during relatively warm and wet interglacials (Agenbroad, 2005; Harington, 1990; Zazula et al., 2014). Despite their different dietary adaptations and dentitions, isolated or fragmentary postcranial elements of mammoths and mastodons are difficult to distinguish. An independent identification method for these genera would be useful and would permit re-evaluation of specimens previously restricted to higherlevel taxonomic identification.

\section{Taxonomic Identification using Stable Isotopes}

Previous research has shown that some animal taxa have distinct isotopic compositions relative to others. If isotopic differences among taxa are relatively consistent at a given location and/or during a given time period, they might be useful for taxonomic identification of skeletal elements that cannot be identified on the basis of discrete morphological or morphometric data. This approach was applied by Thewissen et al. (2001), who used carbon isotopes in bioapatite to support identification of Eocene fossils as cetacean versus artiodactyl or anthracobunid, and by Clementz et al. (2009), who used $\delta^{13} \mathrm{C}$ (collagen and bioapatite) to identify fragmentary archaeological bone samples as sea cow, baleen whale, or sperm whale. While ancient DNA or 
ZooMS ("collagen fingerprinting") analyses would provide more definitive independent identification methods (e.g., Buckley et al., 2014; Buckley and Kansa, 2011; Debruyne et al., 2008; Enk et al., 2011; Poinar et al., 1998), isotopic analysis could potentially provide an easier and less expensive methodology that can also be used to address additional paleobiological questions.

In regions with both $\mathrm{C}_{3}$ and $\mathrm{C}_{4}$ plants, which have very distinct carbon isotope compositions, $\delta^{13} \mathrm{C}$ can be used to distinguish between browsers (such as mastodons) and grazers (such as mammoths) (e.g., Baumann and Crowley, 2015; Koch et al., 1998). Since cold northern regions lack $\mathrm{C}_{4}$ plants, $\delta^{13} \mathrm{C}$ is less useful for identification in these locations, although small differences among herbivore taxa can result from differing plant (part) selection, climate or (micro)habitat, and animal physiology (e.g., Bocherens, 2003). In general, mammoths tend to have higher $\delta^{15} \mathrm{~N}$ (and sometimes lower $\delta^{13} \mathrm{C}_{\mathrm{col}}$ ) than coexisting herbivores (Bocherens, 2003; Bocherens et al., 1994; Fox-Dobbs et al., 2008; Iacumin et al., 2000; Koch, 1991; Kuitems et al., 2012; Metcalfe et al., 2013). Schwartz-Narbonne et al. (2015) demonstrated that the high $\delta^{15} \mathrm{~N}$ of the woolly mammoth resulted from a distinct habitat or diet rather than physiology. Mammoths and mastodons may also have distinct isotopic compositions if they drank from different water sources, as shown for southwestern Ontario and western New York (Metcalfe et al., 2013). These results suggest that an isotopic approach has potential for distinguishing between mammoths and mastodons in $\mathrm{C}_{3}$-dominated environments.

\section{Location-of-Origin Determination using Stable Isotopes}

The use of stable isotope compositions to evaluate location of origin also has precedents in the literature. Stable C, N, O, and H isotope analyses have been extensively utilized to 
determine the location of origin of modern commercial animal products, including milk (Chesson et al., 2010a; Rossmann et al., 1998), cheese (Camin et al., 2012), honey (Chesson et al., 2011), and wool (Hedges et al., 2005). Isotopic compositions have been used to identify the location of origin and life history of human remains (e.g., Corr et al., 2008; Dupras and Schwarcz, 2001; Knudson and Price, 2007; Sharp et al., 2003; White et al., 1998; White et al., 2004), and are increasingly also used to aid in the identification and characterization of forensic remains (Cerling et al., 2003; Ehleringer et al., 2008; Fraser and Meier-Augenstein, 2007; Mays et al., 2011; Meier-Augenstein et al., 2013; O'Brien and Wooller, 2007).

Stable isotope methods for identifying location of origin of animal products and human remains are based on differences in diet and physiology (for $\delta^{13} \mathrm{C}$ and $\delta^{15} \mathrm{~N}$ ) (DeNiro and Epstein, 1978, 1981; Koch et al., 1994), and geographical variations in drinking water (for $\delta^{18} \mathrm{O}$ and $\delta^{2} \mathrm{H}$ ) (Bowen et al., 2005; Bowen and Wilkinson, 2002; Dansgaard, 1964; Ehleringer et al., 2008; Rozanski et al., 1993). In $\mathrm{C}_{3}$-dominated environments such as western Canada, regional differences in climate (e.g., temperature, rainfall) and environment (e.g., canopy cover, soil salinity, water availability, nutrient content) can cause small variations in the $\delta^{13} \mathrm{C}$ of $\mathrm{C}_{3}$ plants, which are passed on to consumers (Arens et al., 2000; Drucker et al., 2008; Kohn, 2010; Murphy and Bowman, 2009; Tieszen, 1991; Van Der Merwe and Medina, 1991). Herbivores occupying different ecological niches may also select plants or plant parts with different $\delta^{13} \mathrm{C}$ values (e.g., Brooks et al., 1997; Tieszen, 1991), leading to different tissue $\delta^{13} \mathrm{C}$. Temporal variations in the proportion and isotopic composition of atmospheric $\mathrm{CO}_{2}$, or in any of the factors described above, can also affect plant and consumer $\delta^{13} \mathrm{C}$ (Arens et al., 2000; Long et al., 2005; Schmitt et al., 2012). In the present study, we expect that differences in $\delta^{13} \mathrm{C}$ among regions will be small (e.g., around 1-3\%), with higher $\delta^{13} \mathrm{C}$ in more arid locations (Kohn, 2010; Stewart et al., 1995). 
The largest variations in nitrogen isotope compositions of animals result from trophic differences (higher $\delta^{15} \mathrm{~N}$ at higher trophic levels), which also affect juveniles consuming their mothers' milk (e.g., Fuller et al., 2006; Jenkins et al., 2001; Metcalfe et al., 2010; Minagawa and Wada, 1984; Rountrey et al., 2007). Herbivores can also have different $\delta^{15} \mathrm{~N}$ values because of environmental conditions (e.g., low rainfall amounts and high temperatures are related to high $\delta^{15} \mathrm{~N}$ in plants), plant selectivity (e.g., plants with mycorrhizal associations tend to have lower $\delta^{15} \mathrm{~N}$ ), or physiology (e.g., nutritional stress can increase animal $\left.\delta^{15} \mathrm{~N}\right)$ (e.g., Amundson et al., 2003; Craine et al., 2009; Drucker et al., 2010; Hartman, 2011; Szpak, 2014; Szpak et al., 2010). If regional differences are observed in the present study, we expect that samples from wetter locations and/or those with less-developed soils (e.g., recently deglaciated landscapes) will have lower $\delta^{15} \mathrm{~N}$ values. The magnitude of differences in $\delta^{15} \mathrm{~N}$ among regions in the present study is likely to be around $7 \%$ or less, based on previous isotopic studies of large mammals in glacial/postglacial Europe (Hedges et al., 2004; Richards and Hedges, 2003; Stevens and Hedges, 2004).

Oxygen isotope compositions of meteoric water decrease with increasing latitude, altitude, and distance from the sea, as a result of variations in temperature, rainfall amount, and the movement of air masses (Dansgaard, 1964; Rozanski et al., 1993; West et al., 2006). For example, modern mean annual meteoric water $\delta^{18} \mathrm{O}$ values are approximately $3.5 \%$ lower in the Klondike region (Mayo, Yukon) than in Edmonton (Alberta) (IAEA/WMO, 2010). Geographic variations in modern meteoric water $\delta^{18} \mathrm{O}$ are well-documented in global isoscape maps (Bowen, 2010; Bowen et al., 2005; Bowen and Wilkinson, 2002; West et al., 2006). Drinking water $\delta^{18} \mathrm{O}$ values are passed on to large-bodied obligate drinkers such as proboscideans, but interpretation of ancient animal $\delta^{18} \mathrm{O}$ can be complicated by climate change, mobility, and non-meteoric water 
sources (e.g., ancient groundwater or glacial meltwater) (Ayliffe et al., 1992; Bryant and Froelich, 1995; Kohn, 1996; Kohn et al., 1996; Levin et al., 2006; Longinelli, 1984). Thus, if isotopic analyses are used to infer location of origin, it is important to establish local baselines for the ancient ecosystems and taxa of interest. Generally, we expect that samples from higherlatitude locations like Klondike and Old Crow will have lower $\delta^{18} \mathrm{O}$ values than samples from lower-latitude or coastal locations like Alberta and British Columbia.

Based on the variations described above, an isotopic approach could be used to investigate the geographic origins of museum specimens. For example, Metcalfe et al. (2013) established a baseline for mammoth and mastodon isotopic compositions in Ontario, and examined three proboscidean specimens that lacked contextual records. A mastodon tooth they examined had isotopic compositions consistent with an origin in southwestern Ontario, whereas two mammoth teeth were extreme outliers. The authors determined that one mammoth likely lived during an interglacial period or in a more southern location, and the other was likely from Klondike, Yukon Territory. In some cases, a similar isotopic approach could also be used to investigate migration: if depositional contexts are secure and environmental change or microhabitat differences are deemed unlikely (e.g., because the same taxa are analyzed), outlying isotopic compositions can indicate migration from distant locations (Hobson and Koehler, 2015; Hoppe, 2004; Keenleyside et al., 2011; Toyne et al., 2014; Webb et al., 2013).

\section{Nutritional Stress: Isotopic Indicators}

The isotopic effects of nutritional stress are generally difficult to distinguish from other factors such as diet, climate, or geographic origins, and the relationship between food stress and isotopic compositions is not always straightforward, particularly among different species (Hatch, 
2012; McCue and Pollock, 2008; Reitsema, 2013). Nevertheless, starvation, leading to catabolism of body tissues, commonly leads to an increase in $\delta^{15} \mathrm{~N}$ of $<+1$ to $+2 \%$ and either no change or a $\leq 1 \%$ increase in $\delta^{13} \mathrm{C}$ (Hatch, 2012; McCue and Pollock, 2008; Reitsema, 2013). Thus, in special circumstances it may be possible to use isotopic compositions of skeletal remains to investigate health (e.g., Olsen et al., 2014). Fossil specimens that record morphological signals of poor health provide an ideal opportunity to evaluate the link between isotopic compositions and nutritional stress.

\section{Materials and Methods}

\section{Samples}

Samples of proboscidean skeletal remains (bone, tusk dentin, and molar enamel, dentin, and cementum) from known geographic localities were obtained from museum collections from British Columbia, Alberta, and Yukon (Table 1, Fig. 1). Only adult teeth and bones were selected, to avoid isotopic variations resulting from nursing (Metcalfe et al., 2010; Rountrey et al., 2007). Most specimens were identified as mammoth or mastodon based on morphology, but a few were identifiable only as proboscidean. The latter were sampled as case studies for taxonomic identification. All samples were selected opportunistically, to avoid damage to museum specimens. Several grams of bone, tooth, and dentin were removed from each specimen using a Dremel tool and/or by manual breakage. Since relatively large amounts of "bulk" bone and dentin ( $\sim 0.5$ to $1.5 \mathrm{~g}$ ) were used for collagen extraction, and because bone does not grow incrementally, collagen samples represent an average of many seasons of growth. There is some potential for seasonal bias in enamel samples, since enamel grows incrementally and smaller 
samples are required for analysis. To minimize bias, we sampled pieces of enamel that represented the entire enamel thickness $(\sim 1-2 \mathrm{~mm})$ and typically $\sim 10 \mathrm{~mm}$ or greater of tooth height, homogenizing the samples for each individual. Growth rate estimates for both mammoth and mastodon molar enamel indicate that more than 1 year is required for the full thickness of the enamel to develop (Metcalfe and Longstaffe, 2012, 2014). Growth in the occlusal-basal direction of mammoth and modern elephant teeth occurs at a rate of 13 to $22 \mathrm{~mm} / \mathrm{a}$, with the faster rates only occurring near the occlusal surface (Dirks et al., 2012; Metcalfe and Longstaffe, 2012; Uno et al., 2013). Occlusal-basal growth rates for mastodon enamel are slower, with a maximum rate of $12 \mathrm{~mm} / \mathrm{a}$ near the occlusal surface and a minimum of $2 \mathrm{~mm} / \mathrm{a}$ near the cervix (Metcalfe and Longstaffe, 2014). Thus, our enamel sampling method averaged seasonal variations in both directions of tooth growth.

One specimen, AB5 (RAM P90.7.1) allowed a unique investigation into the influence of nutritional stress on the isotopic compositions of an extinct megaherbivore. This specimen is a morphologically-normal upper-left M6 with a malformed, supernumerary M7 united to it by hypercementosis (Fig. 2). According to Burns et al. (2003:83):

“The Villeneuve mammoth [AB5 / RAM P90.7.1] was clearly in great pain due to a conspicuous bulging of the buccal alveolus, and it may be argued that it was the ultimate cause of death.... Normal chewing action was eventually rendered impossible. The secondary occlusal facet on the buccal edge of the molar suggests that the mammoth made an effort to avoid the painful passing of the muscle across the bulge... and the animal likely died of malnutrition shortly after cutting the new facet, at age 46 to 48 years, unable to process sufficient graze to survive." 
To examine temporal changes in the collagen $\delta^{13} \mathrm{C}$ and $\delta^{15} \mathrm{~N}$ of this unique specimen, six distinct subsamples were obtained: (1) dentin from the anterior M6, near the occlusal surface, (2) cementum from the anterior M6, near the occlusal surface, (3) M6 root (mostly dentin), (4) cementum joining the M6 and M7, (5) M7 crown cementum, and (6) M7 root (mostly dentin). These subsamples represent different formation times (Appendix S1), and could provide insight into isotopic changes in the mammoth - due to nutritional stress or other causes - prior to death.

\section{Collagen}

Bone, dentin (crown, root, tusk), and cementum were used for collagen analysis. Collagen extraction was modified from Longin (1971), and included demineralization with 0.25$0.5 \mathrm{M} \mathrm{HCl}$ (at room temperature), rinsing to neutrality, humic removal with $0.1 \mathrm{M} \mathrm{NaOH}$ (at room temperature), rinsing to neutrality, and solubilization in $10^{-3} \mathrm{M} \mathrm{HCl}$ at $75-90^{\circ} \mathrm{C}$. Carbon and nitrogen isotope ratios were obtained using a Costech elemental combustion system (ECS4010) coupled to a Thermo-Finnigan Delta ${ }^{\text {Plus }}$ XL stable isotope ratio mass spectrometer (IRMS) operated in continuous-flow mode. The $\delta^{13} \mathrm{C}_{\mathrm{col}}$ values were calibrated to VPDB using ANU-Sucrose (IAEA-CH-6) and NBS-22 (accepted values $=-10.50 \%$ and $-30.03 \%$, respectively), yielding the accepted value of $+1.95 \%$ for NBS-19 (Coplen, 1994; Coplen et al., 2006). The $\delta^{15} \mathrm{~N}_{\text {col }}$ values were calibrated relative to AIR using IAEA N-1 and IAEA N-2 (accepted values $=+0.4$ and $+20.3 \%$, respectively). Carbon and nitrogen contents were also calibrated using the accepted values for the above standards. An internal keratin standard was included in each analytical session to monitor accuracy and precision (mean $\pm 1 \mathrm{SD}: \delta^{13} \mathrm{C}$ measured $=-24.03 \pm 0.06 \%$ o $(\mathrm{n}=77)$, accepted $=-24.04 \% ; \delta^{15} \mathrm{~N}_{\mathrm{col}}$ measured $=+6.29 \pm 0.10 \%$ $(n=77)$, accepted $=+6.36 \%)$. The average difference between duplicate analyses of collagen 
samples was $0.06 \%$ for $\delta^{13} \mathrm{C}$ and $0.11 \%$ for $\delta^{15} \mathrm{~N}_{\text {col }}(\mathrm{n}=16)$. For six individuals, collagen was extracted from multiple tissues (e.g., bone, dentin, cementum) from the same individual. The means of all measurements obtained for each individual are presented in Table 2 . The differences between tissues from the same individuals ranged from 0.3 to $0.7 \%$ for $\delta^{13} \mathrm{C}_{\mathrm{col}}$ and 0.6 to $1.5 \%$ o for $\delta^{15} \mathrm{~N}_{\text {col }}$ (Table 3, Table S1).

\section{Bioapatite}

Only enamel was used for bioapatite analysis, because it is much more resistant to alteration than bone (Ayliffe et al., 1994). Pieces of enamel were mechanically cleaned of adhering dirt, dentin and cementum, sonicated in distilled water 2-3 times (minimum), and examined under an optical microscope prior to being ground to a powder using a mortar and pestle. Aliquots of enamel powder were treated with $\sim 2.5 \% \mathrm{NaOCl}$ at room temperature for $\sim 21$ hours, rinsed five times with de-ionized water, reacted with $0.1 \mathrm{M}$ acetic acid for 4 hours, rinsed as above, and freeze-dried (Garvie-Lok et al., 2004; Koch et al., 1997). Carbon and oxygen isotope compositions were obtained using a MultiPrep automated sampling device (reaction with ortho-phosphoric acid at $90^{\circ} \mathrm{C}$ ) coupled with a VG Optima IRMS in dual-inlet mode. The $\delta^{13} \mathrm{C}$ values were calibrated relative to VPDB using NBS-19 (+1.95\%) and Suprapur $(-35.28 \%)$, and the $\delta^{18} \mathrm{O}$ values were calibrated relative to VSMOW using NBS-19 (+28.6\%) and NBS-18 $(+7.2 \%)$. Accuracy and precision were assessed using standards not included in the calibration curve: NBS-18 $\left(\delta^{13} \mathrm{C}\right.$ measured $=-4.94 \pm 0.10 \%, \mathrm{n}=16$, accepted $\left.=-5.01 \%\right)$, internal laboratory standard WS-1 calcite $\left(\delta^{13} \mathrm{C}\right.$ measured $=+0.76 \pm 0.15 \%, \mathrm{n}=5$, accepted $=+0.76 \% ; ; \delta^{18} \mathrm{O}$ measured $=+26.36 \pm 0.18 \%, n=5$, accepted $=+26.23 \%$ $)$, and Suprapur $\left(\delta^{18} \mathrm{O}\right.$ measured $=$ $+13.15 \pm 0.12 \%, \mathrm{n}=15$, accepted $=+13.25 \%$ ). The average difference between duplicate 
analyses of enamel samples was $0.07 \%$ for $\delta^{13} \mathrm{C}$ and $0.19 \%$ for $\delta^{18} \mathrm{O}(\mathrm{n}=6)$. Carbonate contents were determined using a calibration curve based on the reading of a pressure transducer in the mass spectrometer and the known carbonate contents of calcite standards. Replicate measurements of tooth enamel $\mathrm{CO}_{3}$ contents were within $0.4 \%$ on average (range of offsets $=0.1$ to $0.9 \%$ ).

\section{Statistics}

For isotopic comparisons of mammoths and mastodons within a region (Alberta, Klondike, or Old Crow), an F-test was used to determine whether variances of the two groups were equal, followed by a t-test assuming either equal or unequal variance, as appropriate. For isotopic comparisons among locations (Alberta, Klondike, Old Crow, Herschel Island, and British Columbia), a Kruskall-Wallis non-parametric analysis of variance was used to determine whether there were differences among groups, and a Dunn's multiple comparison test was used to determine which groups differed. For comparisons among locations, British Columbia (BC) and Herschel Island proboscideans specimens that were not identified to genus were compared separately to mammoths and mastodons from other locations. If the unknowns had isotopic compositions more similar to either mammoths or mastodons from the other locations, a case could be made for their inclusion in that genus. An alpha of 0.05 was used for all statistical tests.

\section{Results}

\section{Diagenesis}


The $\mathrm{C} / \mathrm{N}$ ratios, carbon and nitrogen contents, and extraction yields indicate that the collagen samples were well-preserved (Table 2) (Ambrose, 1990; DeNiro, 1985; van Klinken, 1999). Three samples [dentin from AB5 (P90.7.1), AB11 (P00.2.1), and AB6 (P94.4.3)] had C and $\mathrm{N}$ contents (ca. $25-30 \%$ and $10 \%$, respectively) that were slightly lower than is usual for well-preserved collagen, but their $\mathrm{C} / \mathrm{N}$ ratios were normal. Powder X-ray diffraction (pXRD) analysis of the collagen showed that inorganic salts (brushite and halite) were present in these (but not other) samples. Since brushite and halite contain no carbon or nitrogen, the low $\mathrm{C}$ and $\mathrm{N}$ contents were likely caused by the presence of these salts. We note that a variation in the collagen extraction procedure for these samples (i.e., demineralization of large intact chunks of dentin rather than small pieces) rather than poor preservation was likely responsible for the formation of the salts, since the salts only formed in samples extracted using the former method. Based on the results above, the $\delta^{13} \mathrm{C}_{\mathrm{col}}$ and $\delta^{15} \mathrm{~N}_{\mathrm{col}}$ results obtained for these specimens are included in the discussion below.

The carbonate contents of enamel samples $(4.9 \pm 0.8 \%$, Table 2$)$ are similar to those of mature enamel (2.7 to 5.0\%) (Hillson, 1996). Fourier-transform infrared spectroscopy and pXRD analysis of selected pretreated samples indicated no secondary mineral contamination. Thin section analysis of one enamel specimen (AB6 / P94.4.3) revealed clearly visible incremental growth features (e.g., Striae of Retzius, cross-striations). All indicators suggest good preservation of enamel bioapatite.

\section{Taxonomic Identification (Mammoth vs. Mastodon)}


The mean mammoth $\delta^{15} \mathrm{~N}_{\text {col }}$ was higher than that of mastodons in all regions (Table 2, Fig. 3). The difference was significant for Klondike (mean $\delta^{15} \mathrm{~N}_{\mathrm{col}}=+7.5 \mathrm{vs}+4.2 \%$; $\mathrm{t}=7.8, \mathrm{df}=$ 24, $\mathrm{p}<0.001)$ and Old Crow (mean $\delta^{15} \mathrm{~N}_{\mathrm{col}}=+9.1 \mathrm{vs}+3.1 \% ; \mathrm{t}=9.9$, df $\left.=13, \mathrm{p}<0.001\right)$ but not for Alberta (mean $\delta^{15} \mathrm{~N}_{\mathrm{col}}=+7.6 \mathrm{vs}+4.7 \%$; $\left.\mathrm{t}=1.7, \mathrm{df}=5, \mathrm{p}=0.15\right)$. The mean mammoth $\delta^{13} \mathrm{C}_{\text {col }}$ was lower than that of mastodons in all regions, but the difference was only significant for Old Crow (mean $\delta^{13} \mathrm{C}_{\mathrm{col}}=-21.4 \mathrm{vs}-20.1 \%$; $\left.\mathrm{t}=6.6, \mathrm{df}=13, \mathrm{p}<0.001\right)$. Neither $\delta^{13} \mathrm{C}_{\mathrm{sc}}$ nor $\delta^{18} \mathrm{O}_{\mathrm{sc}}$ differed for mammoths and mastodons (note: only Alberta and Klondike had sufficient samples for comparison).

The $\delta^{13} \mathrm{C}_{\mathrm{col}}$ and $\delta^{15} \mathrm{~N}_{\mathrm{col}}$ of BC proboscideans (unidentified to genus) were intermediate between those of mammoths and mastodons from other locations, and did not differ significantly from any other group. Herschel Island unknown proboscideans (unidentified to genus) had significantly different $\delta^{13} \mathrm{C}_{\mathrm{col}}$ and/or $\delta^{15} \mathrm{~N}_{\text {col }}$ from Yukon mastodons (Old Crow and Klondike) (Kruskall-Wallis and Dunn's tests, $\mathrm{p}<0.05$ and $\mathrm{p}<0.001$, for $\delta^{13} \mathrm{C}_{\mathrm{col}}$ and $\delta^{15} \mathrm{~N}_{\text {col }}$, respectively) but did not differ significantly from Yukon mammoths.

\section{Location of Origin}

\section{Collagen Analyses}

Because mammoths and mastodons had significantly different $\delta^{15} \mathrm{~N}_{\mathrm{col}}$ and $\delta^{13} \mathrm{C}_{\mathrm{col}}$ in Old Crow and Klondike, statistical analyses considered the taxa separately for these locations. Mammoth, mastodon, and unknown proboscidean collagen data from Alberta were combined because they did not have significantly different means. BC and Herschel Island samples that 
were not identified to genus were included as separate groups in the statistical analyses, and compared to both mammoths and mastodons from other regions, as described above.

For mastodons, there were no significant differences among locations for $\delta^{13} \mathrm{C}_{\mathrm{col}}$ or $\delta^{15} \mathrm{~N}_{\text {col }}$. For mammoths, there were clear differences among locations for $\delta^{13} \mathrm{C}_{\mathrm{col}}$ (Kruskall-Wallis test, $\mathrm{p}<0.001)$. Dunn's multiple comparison tests showed that differences in mammoth $\delta^{13} \mathrm{C}_{\mathrm{col}}$ existed between Alberta and Old Crow (means of -20.5 vs. $-21.4 \%$ ), Alberta and Herschel Island (means of -20.5 vs. $-21.6 \%$ ), and Klondike and Old Crow (means of -20.7 vs. $-21.4 \%$ ). The Kruskall-Wallis test suggested differences for mammoth $\delta^{15} \mathrm{~N}_{\text {col }}$ in different locations $(\mathrm{p}<0.05)$, but Dunn's multiple comparison tests showed no differences among groups. To be conservative, we assume this contradictory result indicates no reliable significant differences.

\section{Bioapatite Carbonate Analyses}

Bioapatite isotopic compositions for mammoths and mastodons did not differ significantly in any of the regions studied, and were combined within each region in the following comparisons. Results for tooth enamel are available only for Alberta, Klondike, Old Crow, and Herschel Island. The Kruskall-Wallis test showed significant differences among locations for $\delta^{13} \mathrm{C}_{\mathrm{sc}}$ and $\delta^{18} \mathrm{O}_{\mathrm{sc}}(\mathrm{p}<0.001$ in both cases $)$. Dunn's multiple comparison tests showed that differences for $\delta^{13} \mathrm{C}_{\mathrm{sc}}$ existed between Old Crow and Klondike (means of -9.9 vs. $-11.5 \%$ ), and Old Crow and Herschel Island (means of -9.9 vs. $-13.7 \%$ ), whereas differences for $\delta^{18} \mathrm{O}$ existed between Alberta and Old Crow (means of +14.2 vs. $+10.7 \%$ ), and Alberta and Klondike (means of +14.2 vs. $+11.0 \%$ ).

\section{Health Status}


Two of the AB5 (P90.7.1) mammoth subsamples lacked collagen (M6-M7 cementum and M7 root), but data were obtained for the remaining four subsamples (Table 3). Overall, AB5 had the second-highest mean $\delta^{15} \mathrm{~N}_{\mathrm{col}}$ and the lowest $\delta^{13} \mathrm{C}_{\mathrm{col}}$ of any Alberta proboscidean (Table 2). The $\delta^{13} \mathrm{C}_{\mathrm{col}}$ values of all AB5 subsamples were similar, with a range of only $0.4 \%$ (Table 3 ). The $\delta^{15} \mathrm{~N}_{\text {col }}$ values of the three M6 subsamples were very similar, but that of the M7 was considerably lower (by 1.2 to $1.5 \%$ ) (Table 3). Enamel was obtained only from the M6 crown. Its $\delta^{13} \mathrm{C}_{\mathrm{sc}}$ was the lowest of any Alberta proboscidean, but its $\delta^{18} \mathrm{O}$ was not an outlier (Table 2).

\section{Discussion}

\section{Taxonomic Identification}

The data suggest that $\delta^{15} \mathrm{~N}_{\mathrm{col}}$ might be useful for assigning preliminary taxonomic designations (mammoth vs. mastodon) to isolated postcranial remains. Differences in mammoth and mastodon $\delta^{15} \mathrm{~N}_{\text {col }}$ were generally large, as shown previously for other regions (e.g., France et al., 2007; Koch, 1991; Metcalfe et al., 2013), and there were no significant differences among locations in the $\delta^{15} \mathrm{~N}_{\text {col }}$ of either mammoths or mastodons.

\section{Case Study 1: Alberta (individual specimens)}

The unidentified proboscidean bones from Alberta had a range for $\delta^{15} \mathrm{~N}_{\text {col }}$ that exceeded the range for the securely-designated mammoths and mastodons from the same region (Table 2, Fig. 3). Despite the lack of statistical significance for the Alberta mammoth vs. mastodon $\delta^{15} \mathrm{~N}_{\text {col }}$ comparison, we might reasonably hypothesize taxonomic designations for the unknown 
proboscidean bones with the highest and lowest $\delta^{15} \mathrm{~N}_{\text {col }}$ values. We therefore hypothesized that AB3 (P95.1.427) (+10.9\%o) and AB7 (P91.11.9) (+9.0\%) were mammoth, and AB12 (P96.12.1) $(+1.4 \%$ ) was mastodon.

To test our isotopically-derived taxonomic prediction for AB12 (P96.12.1), which had the lowest $\delta^{15} \mathrm{~N}_{\text {col }}$ of any specimen in the present study, we submitted a segment of unprocessed bone (a remainder of the same piece used for isotopic analysis) for ancient DNA analysis. Contrary to expectations, the DNA results suggested that the bone belongs to Mammuthus (Jake Enk and Hendrik Poinar, personal communication, Jan. 30, 2014). To our knowledge, such a low $\delta^{15} \mathrm{~N}_{\text {col }}$ has never been previously reported for Mammuthus. Interestingly, AB12 (P96.12.1) was the only post-glacial specimen from Alberta (directly dated to $10,743 \pm 100{ }^{14} \mathrm{C}$ a BP, BGS 2131) (Burns, 2010), and was recovered further south than the other Alberta individuals analyzed in this study (Table 1, Fig. 1). Thus, it may have inhabited a very different environment than the other (more northern, glacial-aged) specimens. The very low $\delta^{15} \mathrm{~N}_{\text {col }}$ of $\mathrm{AB} 12(\mathrm{P} 96.12 .1)$, as well as the greater variability in Alberta mammoth $\delta^{15} \mathrm{~N}_{\text {col }}$ in general $(\mathrm{SD}=2.4$ for Alberta vs. 1.2 and 1.1\%o for Klondike and Old Crow, respectively) is likely related to Alberta's geographical position at the point of convergence of the Cordilleran and Laurentide Ice Sheets, whose waxing and waning would have had significant effects on the local nitrogen cycle. Both the Alberta and Yukon proboscidean remains were from time-averaged deposits, but only Alberta was repeatedly covered by glacial ice. The so-called ice-free corridor in Alberta not only facilitated gene flow between southern and northern faunal populations (Burns, 1996; Shapiro et al., 2004; Wilson, 1996), but also underwent significant environmental transformations as the ice sheets advanced and receded (Beaudoin and Oetelaar, 2003; Jass et al., 2011), drastically altering the soil-plant nitrogen cycle. Plants and animals in recently deglaciated areas tend to have low $\delta^{15} \mathrm{~N}$ as a result 
of low temperatures, soil immaturity (low nitrogen availability), plant type, and mycorrhizal associations (Drucker et al., 2003; Drucker et al., 2012; Drucker et al., 2011; Hobbie et al., 1999; Hobbie et al., 2000; Szpak, 2014). The first proboscideans to enter Alberta after deglaciation (e.g., AB12 / P96.12.1) would therefore be expected to have had low $\delta^{15} \mathrm{~N}$ values. In contrast, the Yukon locations were never covered by glacial ice and may not have experienced such dramatic environmental shifts, though we note that very low $\delta^{15} \mathrm{~N}$ values have been observed for herbivores in unglaciated northwestern Europe during the Last Glacial Maximum (Dyke et al., 2002; Gautney and Holliday, 2015; Hedges et al., 2004; Richards and Hedges, 2003; Stevens and Hedges, 2004).

Recent research supports the idea that the environmental niches of various proboscidean taxa were broader than traditionally envisioned (Baumann and Crowley, 2015; Metcalfe and Longstaffe, 2014; Saunders et al., 2010). The example of AB12 (P96.12.1) demonstrates that mammoths in Alberta occupied a range of environments, and suggests that taxonomic designations based on stable isotope analyses should ideally be attempted for specimens from known locations and time periods, where baseline isotopic compositions for the taxa in question have already been determined.

\section{Case Study 2: British Columbia and Herschel Island (groups of specimens)}

Unfortunately, the paleontological record is incomplete and it is sometimes not possible to develop baseline isotopic data for all taxa at any given location, such as British Columbia and Herschel Island. BC proboscideans had $\delta^{13} \mathrm{C}_{\mathrm{col}}$ and $\delta^{15} \mathrm{~N}_{\mathrm{col}}$ that were intermediate between those of mammoths and mastodons from other locations, and therefore did not differ significantly from either taxon. Although it is possible that the $\mathrm{BC}$ group includes both mammoths and mastodons, the very small range of $\delta^{15} \mathrm{~N}_{\mathrm{col}}$ for BC specimens (difference of $1.1 \%$ o between maximum and 
minimum values) suggests, rather, that the animals were all of the same taxon. In support of this inference, ancient DNA analysis of BC1 (EH2009.008.0001), BC2 (EH1994.003.0041), BC4, and BC5 (EH1994.003.0040) showed that nine genus-discriminating sites within two speciesdelineable regions of the mitochondrial genome of these individuals matched those of Mammuthus (Jake Enk and Hendrik Poinar, personal communication, Jan. 30, 2014).

Herschel Island specimens not identified to genus had $\delta^{13} \mathrm{C}_{\mathrm{col}}$ and $\delta^{15} \mathrm{~N}_{\text {col }}$ that differed significantly from Old Crow and Klondike mastodons, but were indistinguishable from Old Crow or Klondike mammoths. This suggests that the specimens from Herschel Island were predominantly Mammuthus, an interpretation consistent with the preponderance of mammoth remains, and rarity of mastodon remains, in Alaska and Yukon (Harington, 2003; Zazula et al., 2014).

\section{Location of Origin}

Bioapatite $\delta^{13} \mathrm{C}_{\mathrm{sc}}$ and $\delta^{18} \mathrm{O}_{\mathrm{sc}}$ could be useful for determining locations of origin, as they are quite distinct among several locations (Fig. 4). The oxygen isotope compositions of Old Crow and Klondike specimens are lower than those of Alberta specimens, as expected based on latitudinal variations in meteoric water $\delta^{18} \mathrm{O}$ (Dansgaard, 1964; Rozanski et al., 1993). Contrary to latitude-based expectations, the highest-latitude location (Herschel Island) had relatively high $\delta^{18} \mathrm{O}_{\mathrm{sc}}$ values. This is likely a result of Herschel's close proximity to the sea, where local evaporation of seawater would result in precipitation with a relatively high $\delta^{18} \mathrm{O}$ (Dansgaard, 1964; Rozanski et al., 1993). The similarity in $\delta^{18} \mathrm{O}_{\mathrm{sc}}$ for Old Crow and Klondike specimens is unexpected since they are at different latitudes, but could reflect different atmospheric moisture 
or surface water source regions, and/or temporal differences among the specimens. The carbon isotope compositions of the Herschel Island specimens are strikingly low, which may reflect significantly greater water availability in proximity to the coast (Kohn, 2010). Likewise, the highest $\delta^{13} \mathrm{C}$ values in Old Crow may indicate that the driest conditions were present in that location.

Regardless of the causes of variation, the data presented here provide a baseline for investigating the origins of museum specimens lacking collection data. Alberta specimens can clearly be distinguished from Yukon specimens using $\delta^{13} \mathrm{C}_{\mathrm{sc}}$ and $\delta^{18} \mathrm{O}_{\mathrm{sc}}$ (Fig. 4). Specimens from different regions of Yukon (Klondike, Old Crow, Herschel Island) may also be distinguishable using a combination of $\delta^{18} \mathrm{O}_{\mathrm{sc}}$ and $\delta^{13} \mathrm{C}_{\mathrm{sc}}$ (and possibly $\delta^{13} \mathrm{C}_{\mathrm{col}}$ ), though there is some overlap between Old Crow and Klondike specimens (Fig. 4). Further, because of the predictable change in meteoric water $\delta^{18} \mathrm{O}$ with latitude, $\delta^{18} \mathrm{O}_{\mathrm{sc}}$ could be used to distinguish between regions included in the present study and areas further south. For example, mammoths and mastodons from Ontario and western New York had $\delta^{18} \mathrm{O}_{\text {sc }}$ values between $\sim+19$ and $+23 \%$ (Metcalfe et al., 2013), and mammoths from Arizona had $\delta^{18} \mathrm{O}_{\mathrm{sc}}$ values between $\sim+22$ and $+28 \%$ o (Metcalfe et al., 2011), in contrast to values of $\sim+10$ to $+15 \%$ presented here (all locations combined). Of course, temporal differences among regions can complicate such comparisons, since animals living in colder intervals would have lower $\delta^{18} \mathrm{O}_{\mathrm{sc}}$ than those living in warmer intervals, all else being equal (Ayliffe et al., 1992; Koch, 1998).

Unlike the situation presented here, mammoth and mastodon $\delta^{18} \mathrm{O}$ values may not be the same in every location. For example, in the Great Lakes region there was no overlap between $\delta^{18} \mathrm{O}_{\mathrm{sc}}$ of mammoths and mastodons (Metcalfe et al., 2013). This demonstrates the need for baseline studies in the particular areas and time periods of interest, to determine the range of 
values and degree of overlap among taxa. Only after these are established can comparisons with other regions and inferences about geographic origins be made.

Since knowing the proboscidean taxon was deemed unnecessary for $\delta^{13} \mathrm{C}_{\mathrm{sc}}$ and $\delta^{18} \mathrm{O}_{\mathrm{sc}}$ comparisons, these proxies could be applied to isolated postcranial elements that lack taxonomic designation. However, bone bioapatite is much more susceptible to diagenetic alteration of its isotopic composition, and its analysis (not attempted here) is not recommended (Ayliffe et al., 1994; Koch et al., 1997).

Collagen isotopic compositions were not useful for distinguishing location of origin for mastodons, and were of limited use for mammoths. Although the $\delta^{13} \mathrm{C}_{\mathrm{col}}$ of mammoths in several locations differed significantly, the magnitude of the differences was very small ( $\sim 1 \%$ or less). Compared to these differences among means, variability within a single location was relatively large $(\sim 1-2 \%$ o). As such, it would not be possible to match an isolated specimen to any particular location based on $\delta^{13} \mathrm{C}_{\mathrm{col}}$ alone. However, $\delta^{13} \mathrm{C}_{\mathrm{col}}$ and/or $\Delta^{13} \mathrm{C}_{\mathrm{sc}-\mathrm{col}}$ (the difference between $\delta^{13} \mathrm{C}_{\mathrm{sc}}$ and $\delta^{13} \mathrm{C}_{\mathrm{col}}$, which can be calculated for specimens with isotopic data for both collagen and bioapatite) might provide secondary lines of evidence for location of origin in certain cases. For example, Old Crow mammoths had $\Delta{ }^{13} \mathrm{C}_{\mathrm{sc}-\mathrm{col}}$ values between 10.1 and $13.1 \%$, whereas mammoths and mastodons from other locations had $\Delta^{13} \mathrm{C}_{\mathrm{sc}-\mathrm{col}}$ between 8.0 and $10.1 \%$.

\section{Health Status}

The abnormal M6/M7 (AB5 / P90.7.1) mammoth specimen provides a clear example of a skeletal anomaly that directly impacted the health of the individual, and a unique opportunity for investigating the links between isotopic compositions and nutritional stress in an individual 
extinct animal. The subsamples of the AB5 specimen likely developed in the following order: (1) anterior M6 dentin, (2) anterior M6 cementum, (3) M6 root dentin, (4) M7 crown cementum, (5) cementum between the M6 and M7, (6) M7 root dentin (Appendix S1) (Haynes, 1991; Hillson, 2005; Laws, 1966; Maschenko, 2002; Metcalfe et al., 2010). Unfortunately the two latestdeveloping subsamples lacked collagen, depriving us of data that would have represented the time closest to death. The fact that the M6 root and M7 crown had very distinct $\delta^{15} \mathrm{~N}_{\text {col }}$ values suggests that they formed at different times, with the M7 forming after the M6 was fully developed (Appendix S1). This is in agreement with Burns et al.'s (2003:82) inference that "the M6 was fully erupted when the M7 was forced into place.” The lack of space for the M7 caused the still-developing lamellae to deform as they impacted against the fully-formed M6. Based on this evidence, in combination with elephant tooth development times and the estimated age-atdeath for this specimen, we can surmise that the M7 formed primarily during the last 4-5 years of the animal's life (Appendix S1). It is currently not possible to make a more precise estimate of how much time elapsed between formation of the M7 crown cementum (our latest-developing sample that yielded results) and the animal's death (Appendix S1).

The $\delta^{15} \mathrm{~N}_{\text {col }}$ values of AB5 (P90.7.1) are relatively high, as expected for nutritional stress leading to the catabolism of body tissues, which tends to cause increases of $<+1$ to $+2 \%$ (Hatch, 2012; McCue and Pollock, 2008; Reitsema, 2013). However, contrary to expectations for starvation later in life, the M7 had a lower $\delta^{15} \mathrm{~N}_{\text {col }}$ than the M6 tissues (Table 3). This suggests that body proteins were not being catabolized late in life, during the development of the M7 crown. Nutritional stress leading to reliance on body fats (which would not affect $\delta^{15} \mathrm{~N}$ ) remains a possibility (Hatch, 2012). It is also possible, however, that the relatively high $\delta^{15} \mathrm{~N}$ values reflect the environment in which the animal was living, and are unrelated to nutritional stress. 
The low $\delta^{13} \mathrm{C}$ values of $\mathrm{AB} 5$ (P90.7.1) relative to other Alberta mammoths also do not support expectations for severe starvation and fasting (which tend to have either no effect on tissue $\delta^{13} \mathrm{C}$, or cause a slight increase) (Hatch, 2012; McCue and Pollock, 2008). Although the low $\delta^{13} \mathrm{C}$ values could reflect increased fat metabolism (Bocherens, 2003; Bocherens et al., 1996; Hatch, 2012; Polischuk et al., 2001), there is no difference in the $\delta^{13} \mathrm{C}_{\mathrm{col}}$ of the M6 root and M7 crown, suggesting no change in the last several years prior to death. Together, the differences in $\delta^{13} \mathrm{C}$ and $\delta^{15} \mathrm{~N}$ among subsamples of AB5 suggest a change in diet, environment, or physiology in the years leading up to death, but there is no isotopic evidence for starvation (neither catabolism of body tissues, nor increased reliance on body fats). We emphasize that our data represent some period within approximately 4-5 years of death, but not necessarily the final months/years of the animal's life.

\section{Conclusions}

Stable isotopes can be of use in designating isolated proboscidean skeletal remains as mammoth or mastodon, but such designations remain tentative in the absence of morphological or molecular data. Mammoths tend to have higher $\delta^{15} \mathrm{~N}_{\mathrm{col}}$ and lower $\delta^{13} \mathrm{C}_{\mathrm{col}}$ than mastodons, but the specific range of isotopic compositions differs among geographic locations and time periods, and may not be significantly different in every region. Mammoths, in particular, can have a very large range of $\delta^{15} \mathrm{~N}$ values, as shown for specimens from Alberta. Ideally, taxonomic designations based on stable isotopes should only be attempted for specimens from known locations and time periods, where baseline (preferably non-overlapping) isotopic compositions for the taxa in question have been determined previously. 
We have shown that extraordinary exceptions to general trends in taxonomic differences can exist (i.e., a mammoth with a $\delta^{15} \mathrm{~N}_{\text {col }}$ of $+1.4 \%$ ). This extremely low value may be typical for fauna inhabiting recently-deglaciated late Pleistocene landscapes of Alberta. Further research into the isotopic compositions of plants and animals present at that time and location would be useful to support this hypothesis. This example shows that isotopic analyses may be useful in determining outliers that may be selected for additional research (e.g., DNA, morphology) and may inspire broader research questions. These data also demonstrate the environmental adaptability of Mammuthus.

Our results also demonstrate that stable isotope analysis can be helpful in assigning geographical provenance to isolated museum samples that lack collection data. Bioapatite $\delta^{13} \mathrm{C}_{\mathrm{sc}}$ and $\delta^{18} \mathrm{O}_{\mathrm{sc}}$ are most useful for determining locations of origin, and could be used to distinguish proboscideans from Alberta, Old Crow, Klondike, Herschel Island, and locations further south (e.g., Arizona and the Great Lakes). Collagen $\delta^{13} \mathrm{C}$ could provide a secondary line of evidence for determining the location of origin of mammoths, but $\delta^{15} \mathrm{~N}_{\mathrm{col}}$ was not useful for this application. The isotopic data we have provided can be used as a baseline for future studies of specimens lacking provenance, and are particularly useful since the Yukon is the most prolific source of proboscidean fossils in Canada. It is highly probable that many skeletal remains without provenance in local museum collections are from Yukon, and isotopic determination of their location of origin may be possible. Furthermore, the isotopic baseline we have provided could be used to support inferences of migration, but only if climate-related variations can be ruled out.

The AB5 (P90.7.1) mammoth possessed a dental anomaly that caused impaired chewing, which was hypothesized to have caused nutritional stress and ultimately the animal's death 
(Burns et al., 2003). Our data indicate that in the years prior to its death, the animal experienced a change in diet, environment, or physiology - but not one consistent with nutritional stress. This does not necessarily contradict the interpretation that this animal starved to death (Burns et al., 2003), since the precise amount of time that elapsed between the formation of the analyzed tissues and death remains unknown.

\section{Acknowledgements}

The authors thank Kim Law, Li Huang, Reba Macdonald, and the staff and students of the Laboratory for Stable Isotope Science (LSIS) for laboratory assistance and support, and Ryan Manickchand for photographing the mammoth teeth. Funding for this study was provided by the Natural Sciences and Engineering Research Council of Canada (NSERC Canada Government Scholarship- Doctoral to J.Z.M.; NSERC Discovery Grant 38940 to F.J.L.), the Canada Foundation for Innovation (Grant 2732 to F.J.L.) and the Ontario Research Fund (and its precursors (Grant 2732 to F.J.L.). Research time provided through the Canada Research Chairs program (Grant 950-226925 to F.J.L.) and a Killam Postdoctoral Research Fellowship at UBC (J.Z.M.) is also gratefully acknowledged. This is LSIS Contribution \#331. 


\section{List of Tables}

Table 1. Geographic and temporal context and sampling information for specimens used in this study.

Table 2. The isotopic compositions of collagen (various tissues) and structural carbonate in bioapatite (enamel) for mammoths, mastodons, and unknown proboscideans analyzed in this study and by Zazula el al. (2014).

Table 3. Isotopic results for collagen extracted from different areas on AB5 / P90.7.1 (mammoth M6 and M7).

\section{List of Figures}

Figure 1. Locations mentioned in the text. Red dots indicate provenance for specimens used to establish baseline data for location of origin studies. VI = Vancouver Island, $\mathrm{C}=$ Cochrane, $\mathrm{E} / \mathrm{V}$

$=$ Edmonton/Villeneuve, $\mathrm{B}=$ Bezanson, $\mathrm{K}=$ Klondike, $\mathrm{OC}=$ Old Crow, $\mathrm{H}=$ Herschel Island. Adapted from http://jan.ucc.nau.edu

Figure 2. (A) Lingual view of the sampled left M6/M7 Mammuthus teeth (AB5 / P90.7.1) as compared to (B) the normal condition in a left M6 Mammuthus tooth (P84.5.1). Scale bars $=10$ $\mathrm{cm}$. 
Figure 3. Carbon and nitrogen isotope compositions of collagen for (A) Mammut, (B) unknown proboscideans, and (C) Mammuthus from Western Canada locations.

\author{
Figure 4. Carbon and oxygen isotope results obtained for structural carbonate in enamel \\ bioapatite from Mammuthus (open symbols and stars) and Mammut (closed symbols). Polygons \\ enclose specimens from the different regions. $\mathrm{AB}=$ Alberta, $\mathrm{OC}=$ Old Crow, $\mathrm{K}=\mathrm{Klondike}, \mathrm{H}=$ \\ Herschel Island.
}

\title{
Supplementary Information
}

\author{
Table S1. Isotopic results for collagen extracted from different tissues within the same \\ individuals (excluding AB5).
}

Appendix S1. Developmental timing of the AB5 (P90.7.1) mammoth M6/M7 


\section{References Cited}

Agenbroad LD. 2005. North American proboscideans: Mammoths - the state of knowledge, 2003. Quaternary International 126-28: 73-92.

Ambrose SH. 1990. Preparation and characterization of bone and tooth collagen for isotopic analysis. Journal of Archaeological Science 17: 431-451.

Amundson R, Austin AT, Schuur EAG, Yoo K, Matzek V, Kendall C, Uebersax A, Brenner D, Baisden WT. 2003. Global patterns of the isotopic composition of soil and plant nitrogen. Global Biogeochemical Cycles 17: 1031, doi:1010.1029/2002GB001903.

Arens NC, Jahren AH, Amundson R. 2000. Can $\mathrm{C}_{3}$ plants faithfully record the carbon isotopic composition of atmospheric carbon dioxide? Paleobiology 26: 137-164.

Ayliffe LK, Chivas AR, Leakey MG. 1994. The retention of primary oxygen isotope compositions of fossil elephant skeletal phosphate. Geochimica et Cosmochimica Acta 58: 5291-5298.

Ayliffe LK, Lister AM, Chivas AR. 1992. The preservation of glacial-interglacial climatic signatures in the oxygen isotopes of elephant skeletal phosphate. Palaeogeography Palaeoclimatology Palaeoecology 99: 179-191.

Baumann EJ, Jr., Crowley BE. 2015. Stable isotopes reveal ecological differences amongst nowextinct proboscideans from the Cincinnati region, USA. Boreas 44: 240-254.

Beaudoin AB, Oetelaar GA. 2003. The changing ecophysical landscape of southern Alberta during the late Pleistocene and early Holocene. Plains Anthropologist 48: 187-207.

Bocherens H. 2003. Isotopic biogeochemistry and the paleoecology of the mammoth steppe fauna. Deinsea 9: 57-71.

Bocherens H, Fizet M, Mariotti A, Gangloff RA, Burns JA. 1994. Contribution of isotopic biogeochemistry $\left({ }^{13} \mathrm{C},{ }^{15} \mathrm{~N},{ }^{18} \mathrm{O}\right.$ ) to the paleoecology of mammoths (Mammuthus primigenius). Historical Biology 7: 187-202.

Bocherens H, Pacaud G, Lazarev PA, Mariotti A. 1996. Stable isotope abundances $\left({ }^{13} \mathrm{C},{ }^{15} \mathrm{~N}\right)$ in collagen and soft tissues from Pleistocene mammals from Yakutia: Implications for the palaeobiology of the Mammoth Steppe. Palaeogeography Palaeoclimatology

Palaeoecology 126: 31-44.

Bowen GJ. 2010. Isoscapes: spatial pattern in isotopic biogeochemistry. Annual Review of Earth and Planetary Sciences 38: 161-187.

Bowen GJ, Wassenaar LI, Hobson KA. 2005. Global application of stable hydrogen and oxygen isotopes to wildlife forensics. Oecologia 143: 337-348.

Bowen GJ, Wilkinson B. 2002. Spatial distribution of $\delta^{18} \mathrm{O}$ in meteoric precipitation. Geology 30: $315-318$.

Brooks JR, Flanagan LB, Buchmann N, Ehleringer JR. 1997. Carbon isotope composition of boreal plants: Functional grouping of life forms. Oecologia 110: 301-311.

Bryant JD, Froelich PN. 1995. A model of oxygen-isotope fractionation in body-water of large mammals. Geochimica et Cosmochimica Acta 59: 4523-4537.

Buckley M, Fraser S, Herman J, Melton ND, Mulville J, Palsdottir AH. 2014. Species identification of archaeological marine mammals using collagen fingerprinting. Journal of Archaeological Science 41: 631-641.

Buckley M, Kansa SW. 2011. Collagen fingerprinting of archaeological bone and teeth remains from Domuztepe, South Eastern Turkey. Archaeological and Anthropological Sciences 3: 271-280. 
Burns JA. 1996. Vertebrate paleontology and the alleged ice-free corridor: the meat of the matter. Quaternary International 32: 107-112.

Burns JA. 2010. Mammalian faunal dynamics in Late Pleistocene Alberta, Canada. Quaternary International 217: 37-42.

Burns JA, G. BC, Mol D. 2003. An extraordinary woolly mammoth molar from Alberta, Canada. Deinsea 9: 77-85.

Camin F, Wehrens R, Bertoldi D, Bontempo L, Ziller L, Perini M, Nicolini G, Nocetti M, Larcher R. 2012. H, C, N and S stable isotopes and mineral profiles to objectively guarantee the authenticity of grated hard cheeses. Anal. Chim. Acta 711: 54-59.

Cerling TE, Ehleringer JR, West A, Stange E, Dorigan J. 2003. Forensic applications of stable isotopes in hair. Forensic Science International 136: 172-172.

Chesson LA, Tipple BJ, Erkkila BR, Cerling TE, Ehleringer JR. 2011. B-HIVE: Beeswax hydrogen isotopes as validation of environment. Part I: Bulk honey and honeycomb stable isotope analysis. Food Chemistry 125: 576-581.

Chesson LA, Valenzuela LO, O'Grady SP, Cerling TE, Ehleringer JR. 2010a. Hydrogen and oxygen stable isotope ratios of milk in the United States. Journal of Agricultural and Food Chemistry 58: 2358-2363.

Chesson LA, Valenzuela LO, O'Grady SP, Cerling TE, Ehleringer JR. 2010b. Links between purchase location and stable isotope ratios of bottled water, soda, and beer in the United States. Journal of Agricultural and Food Chemistry 58: 7311-7316.

Clementz MT. 2012. New insight from old bones: stable isotope analysis of fossil mammals. Journal of Mammalogy 93: 368-380.

Clementz MT, Fox-Dobbs K, Wheatley PV, Koch PL, Doak DF. 2009. Revisiting old bones: coupled carbon isotope analysis of bioapatite and collagen as an ecological and palaeoecological tool. Geological Journal 44: 605-620.

Coplen TB. 1994. Reporting stable hydrogen, carbon, and oxygen isotopic abundances. Pure and Applied Chemistry 66: 271-276.

Coplen TB, Brand WA, Gehre M, Groning M, Meijer HAJ, Toman B, Verkouteren RM. 2006. New guidelines for $\delta^{13} \mathrm{C}$ measurements. Analytical Chemistry 78: 2439-2441.

Corr LT, Richards MP, Jim S, Ambrose SH, Mackie A, Beattie O, Evershed RP. 2008. Probing dietary change of the Kwaday Dan Ts'inchi individual, an ancient glacier body from British Columbia: I. Complementary use of marine lipid biomarker and carbon isotope signatures as novel indicators of a marine diet. Journal of Archaeological Science 35: 2102-2110.

Craine JM, Elmore AJ, Aidar MPM, Bustamante M, Dawson TE, Hobbie EA, Kahmen A, Mack MC, McLauchlan KK, Michelsen A, Nardoto GB, Pardo LH, Penuelas J, Reich PB, Schuur EAG, Stock WD, Templer PH, Virginia RA, Welker JM, Wright IJ. 2009. Global patterns of foliar nitrogen isotopes and their relationships with climate, mycorrhizal fungi, foliar nutrient concentrations, and nitrogen availability. New Phytol. 183: 980-992.

Cummings LS, Albert RM. 2007. Phytolith and starch analysis of Dent site mammoth teeth calculus: new evidence for Late Pleistocene mammoth diets and environments, In Frontiers in Colorado Paleoindian Archaeology: From the Dent Site to the Rocky Mountains. Brunswig, R.H., Pitblado, B.L. (eds.) University Press of Colorado: Boulder; 185-192.

Dansgaard W. 1964. Stable isotopes in precipitation. Tellus 16: 436-468. 
Debruyne R, Chu G, King CE, Bos K, Kuch M, Schwarz C, Szpak P, Grocke DR, Matheus P, Zazula G, Guthrie D, Froese D, Buigues B, de Marliave C, Flemming C, Poinar D, Fisher D, Southon J, Tikhonov AN, MacPhee RDE, Poinar HN. 2008. Out of America: Ancient DNA evidence for a New World origin of Late Quaternary woolly mammoths. Current Biology 18: 1320-1326.

DeNiro MJ. 1985. Post-mortem preservation and alteration of "in vivo" bone collagen ratios: implications for paleodietary analysis. Nature 317: 806-809.

DeNiro MJ, Epstein S. 1978. Influence of diet on the distribution of carbon isotopes in animals. Geochimica et Cosmochimica Acta 42: 495-406.

DeNiro MJ, Epstein S. 1981. Influence of diet on the distribution of nitrogen isotopes in animals. Geochimica et Cosmochimica Acta 45: 341-351.

Dirks W, Bromage TG, Agenbroad LD. 2012. The duration and rate of molar plate formation in Palaeoloxodon cypriotes and Mammuthus columbi from dental histology. Quaternary International 255: 79-85.

Dreimanis A. 1967. Mastodons, their geologic age and extinctions in Ontario, Canada. Canadian Journal of Earth Sciences 4: 663-675.

Dreimanis A. 1968. Extinction of mastodons in eastern North America: testing a new climaticenvironmental hypothesis. The Ohio Journal of Science 68: 337-352.

Drucker DG, Bocherens H, Billiou D. 2003. Evidence for shifting environmental conditions in Southwestern France from 33000 to 15000 years ago derived from carbon-13 and nitrogen-15 natural abundances in collagen of large herbivores. Earth and Planetary Science Letters 216: 163-173.

Drucker DG, Bridault A, Cupillard C. 2012. Environmental context of the Magdalenian settlement in the Jura Mountains using stable isotope tracking $\left({ }^{13} \mathrm{C},{ }^{15} \mathrm{~N},{ }^{34} \mathrm{~S}\right)$ of bone collagen from reindeer (Rangifer tarandus). Quaternary International 272: 322-332.

Drucker DG, Bridault A, Hobson KA, Szuma E, Bocherens H. 2008. Can carbon-13 in large herbivores reflect the canopy effect in temperate and boreal ecosystems? Evidence from modern and ancient ungulates. Palaeogeography Palaeoclimatology Palaeoecology 266: 69-82.

Drucker DG, Hobson KA, Ouellet JP, Courtois R. 2010. Influence of forage preferences and habitat use on ${ }^{13} \mathrm{C}$ and ${ }^{15} \mathrm{~N}$ abundance in wild caribou (Rangifer tarandus caribou) and moose (Alces alces) from Canada. Isotopes in Environmental and Health Studies 46: 107121.

Drucker DG, Kind CJ, Stephan E. 2011. Chronological and ecological information on Lateglacial and early Holocene reindeer from northwest Europe using radiocarbon (C-14) and stable isotope (C-13, N-15) analysis of bone collagen: Case study in southwestern Germany. Quaternary International 245: 218-224.

Dupras TL, Schwarcz HP. 2001. Strangers in a strange land: Stable isotope evidence for human migration in the Dakhleh Oasis, Egypt. Journal of Archaeological Science 28: 11991208.

Dyke AS, Andrews JT, Clark PU, England JH, Miller GH, Shaw J, Veillette JJ. 2002. The Laurentide and Innuitian ice sheets during the Last Glacial Maximum. Quaternary Science Reviews 21: 9-31.

Ehleringer JR, Bowen GJ, Chesson LA, West AG, Podlesak DW, Cerling TE. 2008. Hydrogen and oxygen isotope ratios in human hair are related to geography. Proceedings of the National Academy of Sciences of the United States of America 105: 2788-2793. 
Enk J, Devault A, Debruyne R, King CE, Treangen T, O'Rourke D, Salzberg SL, Fisher D, MacPhee R, Poinar H. 2011. Complete Columbian mammoth mitogenome suggests interbreeding with woolly mammoths. Genome Biology 12: R51.

Feranec RS. 2004. Geographic variation in the diet of hypsodont herbivores from the Rancholabrean of Florida. Palaeogeography Palaeoclimatology Palaeoecology 207: 359369.

Fox-Dobbs K, Leonard JA, Koch PL. 2008. Pleistocene megafauna from eastern Beringia: Paleoecological and paleoenvironmental interpretations of stable carbon and nitrogen isotope and radiocarbon records. Palaeogeography Palaeoclimatology Palaeoecology 261: 30-46.

France CAM, Zelanko PM, Kaufman AJ, Holtz TR. 2007. Carbon and nitrogen isotopic analysis of Pleistocene mammals from the Saltville Quarry (Virginia, USA): Implications for trophic relationships. Palaeogeography Palaeoclimatology Palaeoecology 249: 271-282.

Fraser I, Meier-Augenstein W. 2007. Stable H-2 isotope analysis of modern-day human hair and nails can aid forensic human identification. Rapid Communications in Mass Spectrometry 21: 3279-3285.

Fuller BT, Fuller JL, Harris DA, Hedges REM. 2006. Detection of breastfeeding and weaning in modern human infants with carbon and nitrogen stable isotope ratios. American Journal of Physical Anthropology 129: 279-293.

Garvie-Lok SJ, Varney TL, Katzenberg MA. 2004. Preparation of bone carbonate for stable isotope analysis: the effects of treatment time and acid concentration. Journal of Archaeological Science 31: 763-776.

Gautney JR, Holliday TW. 2015. New estimations of habitable land area and human population size at the Last Glacial Maximum. Journal of Archaeological Science 58: 103-112.

Gobetz KE, Bozarth SR. 2001. Implications for late Pleistocene mastodon diet from opal phytoliths in tooth calculus. Quaternary Research 55: 115-122.

Green JL, Semprebon GM, Solounias N. 2005. Reconstructing the palaeodiet of Florida Mammut americanum via low-magnification stereomicroscopy. Palaeogeography Palaeoclimatology Palaeoecology 223: 34-48.

Guthrie RD. 2001. Origin and causes of the mammoth steppe: a story of cloud cover, woolly mammal tooth pits, buckles, and inside-out Beringia. Quaternary Science Reviews 20: 549-574.

Harington CR. 1990. Vertebrates of the last interglaciation in Canada: a review, with new data. Geographie Physique et Quaternaire 44: 375-387.

Harington CR. 2003. Annotated bibliography of Quaternary vertebrates of northern North America, with radiocarbon dates. University of Toronto Press: Toronto.

Hartman G. 2011. Are elevated $\delta^{15} \mathrm{~N}$ values in herbivores in hot and arid environments caused by diet or animal physiology? Functional Ecology 25: 122-131.

Hatch KA. 2012. The use and application of stable isotope analysis to the study of starvation, fasting, and nutritional stress in animals, In Comparative Physiology of Fasting, Starvation, and Food Limitation. McCue, M.D. (Ed.) Springer Berlin Heidelberg; 337364.

Haynes G. 1991. Mammoths, mastodonts, and elephants: biology, behavior, and the fossil record. Cambridge University Press: Cambridge New York.

Hedges REM, Stevens RE, Richards MP. 2004. Bone as a stable isotope archive for local climatic information. Quaternary Science Reviews 23: 959-965. 
Hedges REM, Thompson JMA, Hull BD. 2005. Stable isotope variation in wool as a means to establish Turkish carpet provenance. Rapid Communications in Mass Spectrometry 19: 3187-3191.

Hillson S. 1996. Dental Anthropology. Cambridge University Press: Cambridge.

Hillson S. 2005. Teeth. In Cambridge manuals in archaeology (New York, Cambridge University Press).

Hobbie EA, Macko SA, Shugart HH. 1999. Insights into nitrogen and carbon dynamics of ectomycorrhizal and saprotrophic fungi from isotopic evidence. Oecologia 118: 353-360.

Hobbie EA, Macko SA, Williams M. 2000. Correlations between foliar $\delta^{15} \mathrm{~N}$ and nitrogen concentrations may indicate plant-mycorrhizal interactions. Oecologia 122: 273-283.

Hobson KA, Koehler G. 2015. On the use of stable oxygen isotope $\left(\delta^{18} \mathrm{O}\right)$ measurements for tracking avian movements in North America. Ecology and Evolution 5: 799-806.

Hoppe KA. 2004. Late Pleistocene mammoth herd structure, migration patterns, and Clovis hunting strategies inferred from isotopic analyses of multiple death assemblages. Paleobiology 30: 129-145.

Iacumin P, Nikolaev V, Ramigni M. 2000. C and N stable isotope measurements on Eurasian fossil mammals, 40000 to 10000 years BP: Herbivore physiologies and palaeoenvironmental reconstruction. Palaeogeography Palaeoclimatology Palaeoecology 163: 33-47.

IAEA/WMO. 2010. Global Network of Isotopes in Precipitation. The GNIP Database. Accessible at: http://www.iaea.org/water.

Jass CN, Burns JA, Milot PJ. 2011. Description of fossil muskoxen and relative abundance of Pleistocene megafauna in central Alberta. Canadian Journal of Earth Sciences 48: 793800.

Jenkins SG, Partridge ST, Stephenson TR, Farley SD, Robbins CT. 2001. Nitrogen and carbon isotope fractionation between mothers, neonates, and nursing offspring. Oecologia 129: 336-341.

Keenleyside A, Schwarcz HP, Panayotova K. 2011. Oxygen isotopic evidence of residence and migration in a Greek colonial population on the Black Sea. Journal of Archaeological Science 38: 2658-2666.

Knudson KJ, Price TD. 2007. Utility of multiple chemical techniques in archaeological residential mobility studies: Case studies from Tiwanaku- and Chiribaya-affiliated sites in the Andes. American Journal of Physical Anthropology 132: 25-39.

Koch PL. 1991. The isotopic ecology of Pleisocene proboscideans. Journal of Vertebrate Paleontology 11: 40A.

Koch PL. 1998. Isotopic reconstruction of past continental environments. Annual Review of Earth and Planetary Sciences 26: 573-613.

Koch PL, Fogel ML, Tuross N. 1994. Tracing the diets of fossil animals using stable isotopes, In Stable Isotopes in Ecology and Environmental Science. Lathja, K., Michener, R.H. (eds.) Blackwell Scientific Publications: Oxford; 63-92.

Koch PL, Hoppe KA, Webb SD. 1998. The isotopic ecology of late Pleistocene mammals in North America - Part 1. Florida. Chemical Geology 152: 119-138.

Koch PL, Tuross N, Fogel ML. 1997. The effects of sample treatment and diagenesis on the isotopic integrity of carbonate in biogenic hydroxylapatite. Journal of Archaeological Science 24: 417-429. 
Kohn MJ. 1996. Predicting animal $\delta^{18} \mathrm{O}$ : Accounting for diet and physiological adaptation. Geochimica et Cosmochimica Acta 60: 4811-4829.

Kohn MJ. 2010. Carbon isotope compositions of terrestrial $\mathrm{C}_{3}$ plants as indicators of (paleo)ecology and (paleo)climate. Proceedings of the National Academy of Sciences of the United States of America 107: 19691-19695.

Kohn MJ, Cerling TE. 2002. Stable isotope compositions of biological apatite, In Phosphates: Geochemical, Geobiological, and Materials Importance. Kohn, M.J., Rakovan, J., Hughes, J.M. (eds.) Mineralogical Society of America: Washington, D.C.; 455-488.

Kohn MJ, Schoeninger MJ, Valley JW. 1996. Herbivore tooth oxygen isotope compositions: Effects of diet and physiology. Geochimica et Cosmochimica Acta 60: 3889-3896.

Kuitems M, Kolfschoten T, Plicht J. 2012. Elevated $\delta^{15} \mathrm{~N}$ values in mammoths: a comparison with modern elephants. Archaeological and Anthropological Sciences: 1-7.

Laws RM. 1966. Age criteria for the African elephant, Loxodonta a. africana. East African Wildlife Journal 4: 1-37.

Lepper BT, Frolking TA, Fisher DC, Goldstein G, Sanger JE, Wymer DA, Ogden JG, Hooge PE. 1991. Intestinal contents of a Late Pleistocene mastodont from midcontinental North America. Quaternary Research 36: 120-125.

Levin NE, Cerling TE, Passey BH, Harris JM, Ehleringer JR. 2006. A stable isotope aridity index for terrestrial environments. Proceedings of the National Academy of Sciences of the United States of America 103: 11201-11205.

Long ES, Sweitzer RA, Diefenbach DR, Ben-David M. 2005. Controlling for anthropogenically induced atmospheric variation in stable carbon isotope studies. Oecologia 146: 148-156.

Longin R. 1971. New method of collagen extraction for radiocarbon dating. Nature 230: 241242.

Longinelli A. 1984. Oxygen isotopes in mammal bone phosphate: a new tool for paleohydrological and paleoclimatological research? Geochimica et Cosmochimica Acta 48: $385-390$.

MacFadden BJ, Cerling TE. 1996. Mammalian herbivore communities, ancient feeding ecology, and carbon isotopes: A 10 million-year sequence from the Neogene of Florida. Journal of Vertebrate Paleontology 16: 103-115.

Maschenko E. 2002. Individual development, biology and evolution of the woolly mammoth. Cranium 19: 4-120.

Matheus P, Guthrie RD, Kunz ML. 2003a. Isotope ecology of late Quaternary megafauna in eastern Beringia. In: 3rd International Mammoth Conference, Dawson City and Whitehorse, Yukon, pp. 80-83.

Matheus P, Guthrie RD, Kunz ML. 2003b. Predator-prey links in Pleistocene east Beringia: evidence from stable isotopes. In: 3rd International Mammoth Conference, Dawson City and Whitehorse, Yukon, p. 80.

Mays S, Ogden A, Montgomery J, Vincent S, Battersby W, Taylor GM. 2011. New light on the personal identification of a skeleton of a member of Sir John Franklin's last expedition to the Arctic, 1845. Journal of Archaeological Science 38: 1571-1582.

McAndrews JH, Jackson LJ. 1988. Age and environment of Late Pleistocene mastodont and mammoth in southern Ontario, In Late Pleistocene and Early Holocene Paleoecology and Archeology of the Eastern Great Lakes Region: Proceedings of the Smith Symposium. Laub, R.S., Miller, N.G., Steadman, D.W. (eds.) Buffalo Society of Natural Sciences: Buffalo; 161-172. 
McCue MD, Pollock ED. 2008. Stable isotopes may provide evidence for starvation in reptiles. Rapid Communications in Mass Spectrometry 22: 2307-2314.

Mead JI, Agenbroad LD, Davis OK, Martin PS. 1986. Dung of Mammuthus in the arid southwest, North America. Quaternary Research 25: 121-127.

Meier-Augenstein W, Hobson KA, Wassenaar LI. 2013. Critique: measuring hydrogen stable isotope abundance of proteins to infer origins of wildlife, food and people. Bioanalysis $\mathbf{5}$ : 751-767.

Metcalfe JZ, Longstaffe FJ. 2012. Mammoth tooth enamel growth rates inferred from stable isotope analysis and histology. Quaternary Research 77: 424-432.

Metcalfe JZ, Longstaffe FJ. 2014. Environmental change and seasonal behavior of mastodons in the Great Lakes region inferred from stable isotope analysis. Quaternary Research 82: 366-377.

Metcalfe JZ, Longstaffe FJ, Ballenger JAM, Haynes CV. 2011. Isotopic paleoecology of Clovis mammoths from Arizona. Proceedings of the National Academy of Sciences 108: 1791617920.

Metcalfe JZ, Longstaffe FJ, Hodgins G. 2013. Proboscideans and paleoenvironments of the Pleistocene Great Lakes: landscape, vegetation, and stable isotopes. Quaternary Science Reviews 76: 102-113.

Metcalfe JZ, Longstaffe FJ, Zazula GD. 2010. Nursing, weaning, and tooth development in woolly mammoths from Old Crow, Yukon, Canada: Implications for Pleistocene extinctions. Palaeogeography Palaeoclimatology Palaeoecology 298: 257-270.

Minagawa M, Wada E. 1984. Stepwise enrichment of ${ }^{15} \mathrm{~N}$ along food chains: Further evidence and the relation between $\delta^{15} \mathrm{~N}$ and animal age. Geochimica et Cosmochimica Acta 48: 1135-1140.

Murphy BP, Bowman D. 2009. The carbon and nitrogen isotope composition of Australian grasses in relation to climate. Functional Ecology 23: 1040-1049.

Newsom LA, Mihlbachler MC. 2006. Mastodons (Mammut americanum) diet foraging patterns based on analysis of dung deposits, In First Floridians and Last Mastodons: The PageLadson site in the Auscilla River. Webb, S.D. (Ed.) Springer; 263-331.

O'Brien DM, Wooller MJ. 2007. Tracking human travel using stable oxygen and hydrogen isotope analyses of hair and urine. Rapid Communications in Mass Spectrometry 21: 2422-2430.

Olsen KC, White CD, Longstaffe FJ, von Heyking K, McGlynn G, Grupe G, Ruhli FJ. 2014. Intraskeletal isotopic compositions $\left(\delta^{13} \mathrm{C}, \delta^{15} \mathrm{~N}\right)$ of bone collagen: Nonpathological and pathological variation. American Journal of Physical Anthropology 153: 598-604.

Poinar HN, Hofreiter M, Spaulding WG, Martin PS, Stankiewicz BA, Bland H, Evershed RP, Possnert G, Paabo S. 1998. Molecular coproscopy: Dung and diet of the extinct ground sloth Nothrotheriops shastensis. Science 281: 402-406.

Polischuk SC, Hobson KA, Ramsay MA. 2001. Use of stable-carbon and -nitrogen isotopes to assess weaning and fasting in female polar bears and their cubs. Canadian Journal of Zoology-Revue Canadienne De Zoologie 79: 499-511.

Reitsema LJ. 2013. Beyond diet reconstruction: Stable isotope applications to human physiology, health, and nutrition. American Journal of Human Biology 25: 445-456.

Richards MP, Hedges REM. 2003. Variations in bone collagen $\delta^{13} \mathrm{C}$ and $\delta^{15} \mathrm{~N}$ values of fauna from Northwest Europe over the last 40000 years. Palaeogeography Palaeoclimatology Palaeoecology 193: 261-267. 
Rossmann A, Kornexl B, Versini G, Pichlmayer F, Lamprecht G. 1998. Origin assignment of milk from alpine regions by multielement stable isotope ratio analysis (SIRA). Rivista di Scienza dell'Alimentazione 27: 9-21.

Rountrey AN, Fisher DC, Vartanyan S, Fox DL. 2007. Carbon and nitrogen isotope analyses of a juvenile woolly mammoth tusk: Evidence of weaning. Quaternary International 169: 166-173.

Rozanski K, Araguas-Araguas L, Gonfiantini R. 1993. Isotopic patterns in modern global precipitation, In Climate Change in Continental Isotope Records. Swart, P.K., McKenzie, J., Lohmann, K.C., Savin, S. (eds.) American Geophysical Union: Washington, DC; 1-36.

Saunders JJ. 1996. North American Mammutidae, In The Proboscidea: evolution and palaeoecology of elephants and their relatives. Shoshani, J., Tassy, P. (eds.) Oxford University Press: New York; 271-279.

Saunders JJ, Grimm EC, Widga CC, Campbell GD, Curry BB, Grimley DA, Hanson PR, McCullum JP, Oliver JS, Treworgy JD. 2010. Paradigms and proboscideans in the southern Great Lakes region, USA. Quaternary International 217: 175-187.

Schmitt J, Schneider R, Elsig J, Leuenberger D, Lourantou A, Chappellaz J, Koehler P, Joos F, Stocker TF, Leuenberger M, Fischer H. 2012. Carbon isotope constraints on the deglacial $\mathrm{CO}_{2}$ rise from ice cores. Science 336: 711-714.

Schwartz-Narbonne R, Longstaffe FJ, Metcalfe JZ, Zazula G. 2015. Solving the woolly mammoth conundrum: amino acid ${ }^{15} \mathrm{~N}$-enrichment suggests a distinct forage or habitat. Scientific Reports 5.

Shapiro B, Drummond AJ, Rambaut A, Wilson MC, Matheus PE, Sher AV, Pybus OG, Gilbert MTP, Barnes I, Binladen J, Willerslev E, Hansen AJ, Baryshnikov GF, Burns JA, Davydov S, Driver JC, Froese DG, Harington CR, Keddie G, Kosintsev P, Kunz ML, Martin LD, Stephenson RO, Storer J, Tedford R, Zimov S, Cooper A. 2004. Rise and fall of the Beringian steppe bison. Science 306: 1561-1565.

Sharp ZD, Atudorei V, Panarello HO, Fernández J, Douthitt C. 2003. Hydrogen isotope systematics of hair: archeological and forensic applications. Journal of Archaeological Science 30: 1709-1716.

Stevens RE, Hedges REM. 2004. Carbon and nitrogen stable isotope analysis of northwest European horse bone and tooth collagen, 40,000 BP-present: Palaeoclimatic interpretations. Quaternary Science Reviews 23: 977-991.

Stewart GR, Turnbull MH, Schmidt S, Erskine PD. 1995. ${ }^{13} \mathrm{C}$ natural abundance in plant communities along a rainfall gradient: A biological integrator of water availability Australian Journal of Plant Physiology 22: 51-55.

Szpak P. 2014. Complexities of nitrogen isotope biogeochemistry in plant-soil systems: implications for the study of ancient agricultural and animal management practices. Frontiers in Plant Science 5: 1-19.

Szpak P, Grocke DR, Debruyne R, MacPhee RDE, Guthrie RD, Froese D, Zazula GD, Patterson WP, Poinar HN. 2010. Regional differences in bone collagen $\delta^{13} \mathrm{C}$ and $\delta^{15} \mathrm{~N}$ of Pleistocene mammoths: Implications for paleoecology of the mammoth steppe. Palaeogeography Palaeoclimatology Palaeoecology 286: 88-96.

Thewissen JGM, Williams EM, Roe LJ, Hussain ST. 2001. Skeletons of terrestrial cetaceans and the relationship of whales to artiodactyls. Nature 413: 277-281.

Tieszen LL. 1991. Natural variations in the carbon isotope values of plants: Implications for archaeology, ecology, and paleoecology. Journal of Archaeological Science 18: 227-248. 
Toyne JM, White CD, Verano JW, Uceda Castillo S, Millaire JF, Longstaffe FJ. 2014. Residential histories of elites and sacrificial victims at Huacas de Moche, Peru, as reconstructed from oxygen isotopes. Journal of Archaeological Science 42: 15-28.

Uno KT, Quade J, Fisher DC, Wittemyer G, Douglas-Hamilton I, Andanje S, Omondi P, Litoroh M, Cerling TE. 2013. Bomb-curve radiocarbon measurement of recent biologic tissues and applications to wildlife forensics and stable isotope (paleo)ecology. Proceedings of the National Academy of Sciences of the United States of America 110: 11736-11741.

Van Der Merwe NJ, Medina E. 1991. The canopy effect, carbon isotope ratios and foodwebs in Amazonia. Journal of Archaeological Science 18: 249-260.

van Geel B, Aptroot A, Baittinger C, Birks HH, Bull ID, Cross HB, Evershed RP, Gravendeel B, Kompanje EJO, Kuperus P, Mol D, Nierop KGJ, Pals JP, Tikhonov AN, van Reenen G, van Tienderen PH. 2008. The ecological implications of a Yakutian mammoth's last meal. Quaternary Research 69: 361-376.

van Klinken GJ. 1999. Bone collagen quality indicators for paleodietary and radiocarbon measurements. Journal of Archaeological Science 26.

Webb EC, White CD, Longstaffe FJ. 2013. Exploring geographic origins at Cahuachi using stable isotopic analysis of archaeological human tissues and modern environmental waters. International Journal of Osteoarchaeology 23: 698-715.

West JB, Bowen GJ, Cerling TE, Ehleringer JR. 2006. Stable isotopes as one of nature's ecological recorders. Trends in Ecology \& Evolution 21: 408-414.

White CD, Spence MW, Stuart-Williams HL, Schwarcz HP. 1998. Oxygen isotopes and the identification of geographical origins: the Valley of Oaxaca versus the Valley of Mexico. Journal of Archaeological Science 25: 643-655.

White CD, Storey R, Longstaffe FJ, Spence MW. 2004. Immigration, assimilation, and status in the ancient city of Teotihuacan: stable isotope evidence from Tlajinga 33. Latin American Antiquity 15: 176-198.

Wilson MC. 1996. Late Quaternary vertebrates and the opening of the ice-free corridor, with special reference to the genus Bison. Quaternary International 32: 97-105.

Yansa CH, Adams KM. 2012. Mastodons and mammoths in the Great Lakes region, USA and Canada: New insights into their diets as they neared extinction. Geography Compass 6: 175-188.

Zazula GD, MacPhee RDE, Metcalfe JZ, Reyes AV, Brock F, Druckenmiller PS, Groves P, Harington CR, Hodgins GWL, Kunz ML, Longstaffe FJ, Mann DH, McDonald HG, Nalawade-Chavan S, Southon JR. 2014. American mastodon extirpation in the Arctic and Subarctic predates human colonization and terminal Pleistocene climate change.

Proceedings of the National Academy of Sciences 111: 18460-18465. 
Table 1 Geographic and temporal context and sampling information for specimens used in this stud:

\begin{tabular}{|c|c|c|c|c|c|c|c|c|c|c|c|}
\hline \multicolumn{2}{|c|}{ Specimen } & \multirow[b]{2}{*}{ Museum \# } & \multirow[b]{2}{*}{ Taxon } & \multirow[b]{2}{*}{ Area } & \multirow[b]{2}{*}{ Site } & \multirow[b]{2}{*}{ Tissues } & \multirow[b]{2}{*}{ Bone element } & \multirow[b]{2}{*}{ Tooth } & \multicolumn{2}{|c|}{ Radiocarbon } & \multirow[b]{2}{*}{ Ref } \\
\hline LSIS \# & Source & & & & & & & & Date $\left({ }^{14} \mathrm{C}\right.$ a BP $)$ & Lab \# & \\
\hline \multicolumn{12}{|c|}{ British Columbia } \\
\hline $\mathrm{BC} 1$ & $\mathrm{RBCM}$ & EH2009.008.0001 & Proboscidea & Vanc. Island & Island View Beacr & $\mathrm{T}$ & & tusk & & & \\
\hline $\mathrm{BC} 2$ & $\mathrm{RBCM}$ & EH1994.003.0041 & Proboscidea & Vanc. Island & Cordova Bay & $\mathrm{T}^{*}$ & & tusk & & & 1 \\
\hline BC3-1 & RBCM & EH1994.003.0039 & Proboscidea & Vanc. Island & Cordova Bay & $\mathrm{T}$ & & tusk & & & 1 \\
\hline $\mathrm{BC} 4$ & UWO & & Proboscidea & Northern BC & & $\mathrm{T}$ & & tusk & & & \\
\hline BC5 & RBCM & EH1994.003.0040 & Proboscidea & Vanc. Island & Cordova Bay & B & humerus & & $17,000 \pm 240$ & GSC-2829 & 1 \\
\hline \multicolumn{12}{|c|}{ 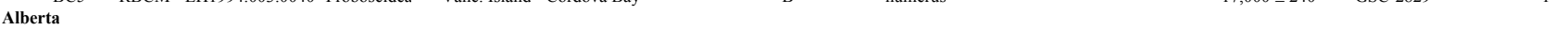 } \\
\hline $\mathrm{AB} 1$ & RAM & P97.11.1B & Mammuthus & Edmonton & Riverview Pit & $\mathrm{B}, \mathrm{D}, \mathrm{C}, \mathrm{E}$ & mandibular symphysis & LLM6 & $43,300 \pm 3000$ & & 2 \\
\hline $\mathrm{AB} 2$ & RAM & P94.1.698 & Mammuthus & Edmonton & Consolidated Concrete Pit $4 \varepsilon$ & $\mathrm{D}, \mathrm{C}, \mathrm{E}$ & & URM5 & $>37,700$ & AA84996 & 2,3 \\
\hline $\mathrm{AB} 3$ & RAM & P94.1.427 & Proboscidea & Edmonton & Consolidated Concrete Pit $4 \varepsilon$ & B & left innominate & & & & 2,3 \\
\hline $\mathrm{AB} 4$ & RAM & P94.16.1B & Mammut & Edmonton & Apex Galloway Pit & $\mathrm{B}, \mathrm{D}, \mathrm{E}$ & mandible (ascending ramus & LRM5 & & & 3 \\
\hline AB5 & RAM & P90.7.1 & Mammuthus & Villeneuve & Alberta Conceret Products Ltd. & $\mathrm{D}, \mathrm{C}, \mathrm{E}$ & & ULM6+M7 & & & 4 \\
\hline $\mathrm{AB} 6$ & RAM & P94.4.3 & Mammuthus & Villeneuve & Consolidated Concrete Pit 46 & $\mathrm{D}, \mathrm{C}^{*}, \mathrm{E}$ & & LLM6 & & & 3 \\
\hline AB7 & RAM & P91.11.9 & Proboscidea & Villeneuve & Consolidated Concrete Pit 46 & B & cortical & & & & 3 \\
\hline AB8 & RAM & P94.4.1 & Proboscidea & Villeneuve & Consolidated Concrete Pit $4 t$ & B & right scapula & & & & 3 \\
\hline $\mathrm{AB} 9$ & RAM & P94.4.2 & Mammuthus & Villeneuve & Consolidated Concrete Pit 46 & $\mathrm{C}^{*}$ & & URM6 & & & 3 \\
\hline $\mathrm{AB} 10$ & RAM & P97.7.1 & Maтmut & Villeneuve & Consolidated Concrete Pit 46 & $\mathrm{D}, \mathrm{E}$ & & LLM6 & $>41,100$ & AA84997 & 3 \\
\hline $\mathrm{AB} 11$ & RAM & P00.2.1 & Mammuthus & Bezanson & Smoky River & $\mathrm{D}, \mathrm{C}, \mathrm{E}$ & & LRM4/M5 & $40,000 \pm 3500$ & AA84979 & \\
\hline $\mathrm{AB} 12$ & RAM & P96.12.1 & Proboscidea & Cochrane & Burnco Pit & B & humerus (deltoid tuberosity' & & $10,743 \pm 100$ & BGS 2141 & 5 \\
\hline \multicolumn{12}{|c|}{ 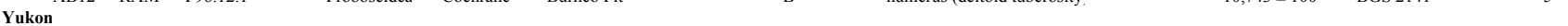 } \\
\hline YT1 & YG & 291.1 & Mammuthus & Old Crow & Old Crow River & $\mathrm{RD}, \mathrm{E}$ & & LRM6 & $>41,100$ & AA84987 & 6 \\
\hline YT2 & YG & 122.2 & Mammuthus & Old Crow & CRH 94 & $\mathrm{RD}, \mathrm{E}$ & & ULM6 & $>41,100$ & AA84992 & 6 \\
\hline YT3 & YG & 173.5 & Mammuthus & Old Crow & Ch'ijee's Bluff & $\mathrm{D}, \mathrm{E}$ & & U M6 & & & 6 \\
\hline YT4 & YG & 285.1 & Mammuthus & Old Crow & OCR, REM 78-1 & $\mathrm{B}, \mathrm{E}$ & & LRM6 & $>39,100$ & AA85002 & 6 \\
\hline YT5 & YG & 60.2 & Mammuthus & Old Crow & OCR, Bluffs-R bank & $\mathrm{RD}, \mathrm{E}$ & & LRM5/M6 & & & 6 \\
\hline YT6 & YG & 57.1 & Mammuthus & Old Crow & OCR, Bluffs-R bank & $\mathrm{C}, \mathrm{E}$ & & LRM6 & & & 6 \\
\hline YT7 & YG & 325.22 & Mammuthus & Old Crow & HH-68-10 & $\mathrm{B}, \mathrm{E}$ & & ULM6 & $>40,100$ & AA84984 & 6 \\
\hline YT8 & YG & 357.1 & Maтmиt & Old Crow & Old Crow River & $\mathrm{D}, \mathrm{E}$ & & M5/M6 & $>41,100$ & AA84995 & \\
\hline YT9 & YG & 284.4 & Mammuthus & Old Crow & CRH 11 & $\mathrm{C}, \mathrm{E}$ & & ULM6 & & & 6 \\
\hline YT10 & YG & 252.2 & Mammuthus & Old Crow & CRH 20 & $\mathrm{RD}, \mathrm{E}$ & & LLM6 & $>40,000$ & AA85001 & 6 \\
\hline YT11 & YG & 173.1 & Mammuthus & Old Crow & Ch'ijee's Bluff & $\mathrm{RD}, \mathrm{C}, \mathrm{E}$ & & U M6 & & & 6 \\
\hline YT24 & YG & 78.1 & Mammuthus & Klondike & Last Chance Creek & $\mathrm{RD}, \mathrm{E}$ & & M6 & $>48,800$ & UCIAMS41491 & 7 \\
\hline YT25 & YG & 2.16 & Mammuthus & Klondike & Hester Creek & $\mathrm{C}, \mathrm{E}$ & & adult & & & \\
\hline YT26 & YG & 2.14 & Mammuthus & Klondike & Hester Creek & $\mathrm{C}, \mathrm{E}$ & & adult & $35,500 \pm 2000$ & AA84986 & \\
\hline YT27 & YG & 29.248 & Mammuthus & Klondike & Hunker Creek & B & mandible & & $43,500 \pm 1900$ & UCIAMS41493 & 7 \\
\hline YT28a,b & YG & $6.51,6.49$ & Mammuthus & Klondike & Gold Run Creek & $\mathrm{B}, \mathrm{E}$ & mandible & LLM6,LRM6 & $17,950 \pm 120$ & Beta 70099 & \\
\hline YT29 & YG & 358.1 & Mammuthus & Klondike & & B, E & mandible & M6 & & & \\
\hline YT30 & YG & 302.26 & Mammuthus & Klondike & Skookum Gulch & $B, E$ & mandible & M5/M6 & $>39,200$ & AA84983 & \\
\hline YT31 & YG & 2.4 & Mammuthus & Klondike & Hester Creek & $\mathrm{B}, \mathrm{E}$ & mandible & M6? & $27,380 \pm 730$ & AA85000 & \\
\hline YT32 & YG & 84.1 & Mammuthus & Klondike & Hunker Creek & $\mathrm{C}, \mathrm{E}$ & & adult & & & \\
\hline YT33 & YG & 159.83 & Maтmиt & Klondike & Quartz Creek & B & fibula & & & & \\
\hline YT34 & YG & 43.2 & Maттит & Klondike & Upper Gold Run & $\mathrm{RD}, \mathrm{E}$ & & M6 & $>49,200$ & UCIAMS75320 & 8 \\
\hline YT35 & YG & 26.1 & Mammut & Klondike & Gold Run Creek & $\mathrm{RD}, \mathrm{E}$ & & M6 & $>50,300 ;>51,700$ & UCIAMS 78705,78704 & 8 \\
\hline YT36 & YG & 50.1 & Maтmut & Klondike & Thistle Creek & $\mathrm{RD}, \mathrm{E}$ & & M5? & $>41,100$ & AA84994 & \\
\hline YT37 & YG & 139.5 & Maтmит & Klondike & Unknown? & $\mathrm{B}, \mathrm{E}$ & mandible & M6 & $>41,100$ & AA84985 & \\
\hline YT38 & YG & 33.3 & Maтmит & Herschel & Simpson Point & B & cuboid & & $>45130$ & Beta 189291 & 9 \\
\hline YT39 & YG & 68.2 & Mammuthus & Herschel & Simpson Point & $\mathrm{D}, \mathrm{E}$ & & fragment & & & \\
\hline YT40 & YG & 68.4 & Mammuthus & Herschel & Simpson Point & $\mathrm{C}, \mathrm{E}$ & & fragment & $>35,900$ & AA84988 & \\
\hline YT41 & YG & 154.2 & Proboscidea & Herschel & South Shore & $\mathrm{T}$ & & tusk & & & \\
\hline YT42 & YG & 12.9 & Proboscidea & Herschel & Simpson Point & $\mathrm{T}$ & & tusk & $34,100 \pm 1,700$ & AA84999 & \\
\hline YT43 & YG & 206.29 & Proboscidea & Herschel & Simpson Point & $\mathrm{T}$ & & tusk & & & \\
\hline YT44 & YG & 33.7 & Proboscidea & Herschel & Simpson Point & $\mathrm{T}$ & & tusk & & & \\
\hline YT45 & YG & 68.1 & Proboscidea & Herschel & Simpson Point & $\mathrm{T}$ & & tusk & $>39,400$ & AA84982 & \\
\hline YT46 & YG & 271.93 & Mammuthus & Herschel & Simpson Point & B & thoracic vertebra & & & & \\
\hline YT47 & YG & 2.7 & Mammuthus & Klondike & Hester Creek & B & fibula & & $27,540 \pm 270$ & UCIAMS 41488 & 7 \\
\hline YT48 & YG & 133.21 & Mammuthus & Klondike & Whitman Gulch & B & right tibia & & $34,180 \pm 590$ & UCIAMS41489 & 7 \\
\hline YT49 & YG & 5.46 & Mammuthus & Klondike & Hunker Creek & B & rib & & $22,430 \pm 140$ & UCIAMS41487 & 7 \\
\hline YT50 & YG & 219.3 & Mammuthus & Stewart River & r Ash Bend & B & long bone fragments & & & & \\
\hline YT51 & YG & 317.51 & Mammuthus & Old Crow & CRH 11 & $\mathrm{~T}$ & & tusk & MIS5, $\sim 140,000$ & & \\
\hline
\end{tabular}

LSIS \#: Sample ID used for Laboratory for Stable Isotope Science analyses, and referred to in this stud

Source of skeletal materials: RBCM = Royal British Columbia Museum, RAM = Royal Alberta Museum, YG = Yukon Government, $\mathrm{CMN}=$ Canadian Museum of Nature

Tissues: $\mathrm{T}=$ tusk, $\mathrm{B}=$ bone, $\mathrm{D}=$ dentin $($ crown $), \mathrm{RD}=$ root dentin, $\mathrm{C}=$ cementum, $\mathrm{E}=$ ename

Radiocarbon dates in bold were obtained as part of the present stud:

* Insufficient collagen preservation; no dat

References

1 Keddie, 1979

2 Burns and Young, 1994

3 Young et al., 1994

4 Burns et al., 2003

5 Burns, 2010

6 Metcalfe et al., 2010

7 Debruyne et al., 2008

8 Zazula et al., 201

9 Zazula et al., 2009 
Table 2. The isotopic compositions of collagen (various tissues) and structural carbonate in bioapatite (enamel) for mammoths, mastodons, and unknown proboscideans analyzed in this study and by Zazula et al. (2014).

\begin{tabular}{|c|c|c|c|c|c|c|c|c|c|c|c|c|c|}
\hline \multirow[b]{2}{*}{ Region } & \multirow[b]{2}{*}{ LSIS \# } & \multicolumn{7}{|c|}{ Collagen } & & \multicolumn{4}{|c|}{ Structural carbonate } \\
\hline & & $\begin{array}{c}\text { Tissue } \\
\text { used }\end{array}$ & $\begin{array}{c}\mathrm{C} \\
(\%)\end{array}$ & $\begin{array}{l}\delta^{13} \mathrm{C} \\
(\% 0)\end{array}$ & $\begin{array}{c} \\
(\%)\end{array}$ & $\begin{array}{l}\delta^{15} \mathrm{~N} \\
(\% \circ)\end{array}$ & $\underset{\text { (Atomic) }}{\mathbf{C} / \mathbf{N}}$ & $\begin{array}{c}\text { Yield } \\
(\%)\end{array}$ & Lab* & $\begin{array}{c}\text { Tissue } \\
\text { used }\end{array}$ & $\begin{array}{l}\delta^{13} \mathrm{C} \\
(\% \circ)\end{array}$ & $\begin{array}{c}\delta^{18} \mathrm{O} \\
(\%)\end{array}$ & $\begin{array}{l}\mathrm{CO}_{3} \\
(\%)\end{array}$ \\
\hline
\end{tabular}

\section{British Columbia}

\begin{tabular}{lcccccccc} 
Proboscidea & & & & & & & \\
BC1 & $\mathrm{T}$ & 38.4 & -19.9 & 14.2 & +7.0 & 3.2 & 4.3 & LSIS \\
BC3-1 & $\mathrm{T}$ & 42.4 & -20.7 & 15.8 & +6.9 & 3.1 & 6.3 & LSIS \\
BC4 & $\mathrm{T}$ & 47.0 & -21.3 & 17.4 & +6.9 & 3.1 & 22.9 & LSIS \\
BC5 & $\mathrm{B}$ & 41.3 & -21.3 & 15.2 & +5.9 & 3.2 & 11.0 & LSIS \\
\hline Mean & & 42.3 & -20.8 & 15.7 & +6.7 & 3.1 & 11.1 & \\
SD & & 3.6 & 0.7 & 1.3 & 0.5 & 0.0 & 8.3 &
\end{tabular}

Alberta

\begin{tabular}{lcccccccc} 
Proboscidea & & & & & & & \\
AB3 & B & $\mathbf{4 2 . 0}$ & $\mathbf{- 2 0 . 5}$ & $\mathbf{1 5 . 8}$ & $\mathbf{+ 1 0 . 9}$ & $\mathbf{3 . 1}$ & 11.0 & LSIS \\
AB7 & B & 41.5 & -20.4 & 16.3 & +9.0 & 3.0 & 10.9 & LSIS \\
AB8 & B & $\mathbf{3 9 . 9}$ & $\mathbf{- 1 9 . 7}$ & $\mathbf{1 4 . 8}$ & $+\mathbf{+ 4 . 4}$ & $\mathbf{3 . 1}$ & 7.5 & LSIS \\
AB12 & B & 32.8 & -21.0 & 12.1 & +1.4 & 3.2 & 4.3 & LSIS \\
\hline Mean & & 39.0 & -20.4 & 14.8 & +6.4 & 3.1 & 8.5 &
\end{tabular}

Mammuthus

\begin{tabular}{|c|c|c|c|c|c|c|c|c|c|c|c|c|}
\hline AB1 & B,C,D & 40.9 & -20.6 & 15.6 & +7.8 & 3.1 & $>5.9$ to 16.0 & LSIS & E & -10.7 & +14.2 & 4.0 \\
\hline AB2 & C, D & 36.1 & -21.1 & 13.3 & +9.7 & 3.2 & 14.4 to $>15.5$ & AMS/LSIS & E & -11.4 & +15.0 & 6.8 \\
\hline AB5 & C, D & 36.1 & -21.4 & 13.0 & +10.0 & 3.2 & 5.3 & LSIS & E & -11.5 & +13.6 & 4.9 \\
\hline AB6 & $\mathrm{D}$ & 28.0 & -20.1 & 10.2 & +5.1 & 3.2 & $>14.7$ & LSIS & $\mathrm{E}$ & -10.7 & +15.2 & 5.6 \\
\hline AB11 & C, D & 34.9 & -20.6 & 13.0 & +5.5 & 3.1 & $>4.3$ to 16.1 & AMS/LSIS & $\mathrm{E}$ & -10.5 & +13.1 & 5.9 \\
\hline$\overline{\text { Mean }}$ & & 35.2 & -20.8 & 13.0 & +7.6 & 3.2 & & & & -10.9 & +14.2 & 5.4 \\
\hline SD & & 4.6 & 0.5 & 1.9 & 2.3 & 0.1 & & & & 0.5 & 0.9 & 1.1 \\
\hline \multicolumn{13}{|l|}{ Іатmиt } \\
\hline AB4 & B, D & 40.3 & -20.8 & 15.0 & +4.5 & 3.1 & $>11.9$ to 13.6 & LSIS & E & -11.6 & +14.9 & 3.6 \\
\hline $\mathrm{AB} 10$ & $\mathrm{D}$ & 41.1 & -19.5 & 15.4 & +5.0 & 3.1 & 12.4 & AMS & E & -10.3 & +13.5 & 4.0 \\
\hline Mean & & 40.7 & -20.1 & 15.2 & +4.7 & 3.1 & & & & -10.9 & +14.2 & 3.8 \\
\hline
\end{tabular}




\section{SD}

$\begin{array}{lllll}0.6 & 0.9 & 0.3 & 0.4 & 0.0\end{array}$

0.9

1.0

0.3

Yukon - Klondike

Mammuthus

YT24

$\mathrm{RD}$

$45.7-20.8$

16.9

$+8.2=\frac{10}{3.2}$

20.2

YT25
YT26

YT27

YT28

YT29

YT30

YT31

YT32

YT47

YT48

YT49

Mean

SD

Mammut

YT33

YT34

YT35

YT36

YT37

C $\quad 42.0$

$-21.2$

$\begin{array}{lll}16.9 & +8.2 & 3.2 \\ 15.5 & +8.0 & 3.2\end{array}$

20.2
7.3

LSIS

LSIS

AMS

13.5

LSIS

$\begin{array}{lll}\text { B } & \mathbf{4 4 . 4} & \mathbf{- 2 1 . 1} \\ \text { B } & 47.5 & -20.7\end{array}$

$\begin{array}{lll}16.0 & +7.4 & 3.2 \\ \mathbf{1 6 . 3} & +\mathbf{7 . 0} & \mathbf{3 . 2}\end{array}$

19.1

LSIS

12.7 LSIS

$\begin{array}{llllllll}\text { B } & 41.5 & -20.3 & 15.6 & +5.8 & 3.1 & 18.0 & \text { AMS } \\ \text { B } & 37.8 & -20.5 & 14.1 & +7.0 & 3.1 & 13.0 & \text { AMS }\end{array}$

$\begin{array}{llllllll}\mathrm{B} & 37.8 & -20.5 & 14.1 & +7.0 & 3.1 & 13.0 & \text { AMS } \\ \mathrm{C} & 45.9 & -20.7 & 16.9 & +7.7 & 3.2 & 12.4 & \text { LSIS }\end{array}$

$45.9-20.7$

$+7.7 \quad 3.2$

16.8

LSIS

$\begin{array}{lllllll}46.6 & -20.7 & 17.3 & +6.8 & 3.1 & 21.0 & \text { LSIS }\end{array}$

$\begin{array}{lllll}46.6 & -20.7 & 17.3 & +6.8 & 3.1\end{array}$

21.0

LSIS

\begin{tabular}{cccccc}
$\mathrm{B}$ & 35.9 & -20.8 & 12.9 & +7.2 & 3.3 \\
\hline & 43.4 & -20.7 & 16.0 & +7.5 & 3.2 \\
& 3.5 & 0.3 & 1.4 & 1.2 & 0.0
\end{tabular}

3.3

1.2

LSIS

$\begin{array}{ccc}-11.7 & +11.1 & 4.9 \\ 0.4 & 0.9 & 1.0\end{array}$

1 CMN333

$\begin{array}{llllll}\text { B } & 43.2 & -20.9 & 15.8 & +6.9 & 3.2\end{array}$

5.7

LSIS

$\begin{array}{llllll}\mathrm{RD} & 45.7 & -20.0 & 16.9 & +4.5 & 3.2\end{array}$

18.5

LSIS

$\begin{array}{ll}18.4 & \text { LSIS } \\ 19.9 & \text { AMS }\end{array}$

$\begin{array}{llllll}\mathrm{RD} & 42.4 & -20.6 & 16.0 & +4.4 & 3.1 \\ \mathrm{RD} & 41.7 & -21.2 & 15.6 & +4.3 & 3.1\end{array}$

AMS

14.5 AMS

$\begin{array}{llll}\text { E } & -11.34 & +10.8 & 4.9\end{array}$

$\begin{array}{llll}\mathrm{E} & -11.3 & +10.4 & 4.0\end{array}$

CMN333

$\begin{array}{llllll}\mathrm{D} / \mathrm{RD} & 43.6 & \mathbf{2 0 . 6} & \mathbf{1 5 . 4} & \mathbf{+ 4 . 1} & \mathbf{3 . 3}\end{array}$

6.1

UCI

1 CMN33897

$\mathrm{D} / \mathrm{RD}$

$\begin{array}{lllll}43.6 & -20.6 & \mathbf{1 5 . 4} & +4.1 & \mathbf{3 . 3} \\ 42.7 & -19.9 & 15.7 & +4.9 & 3.2\end{array}$

7.6

$\mathrm{UCI}$

1 CMN 8707

$\begin{array}{llllll}\mathrm{D} / \mathrm{RD} & 42.9 & -20.8 & 15.6 & +4.3 & 3.2\end{array}$

8.4

$\mathrm{UCI}$

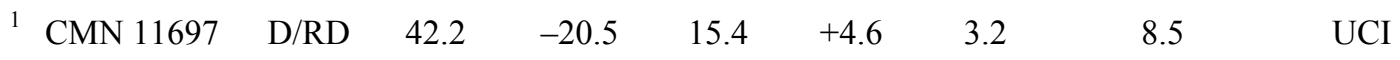

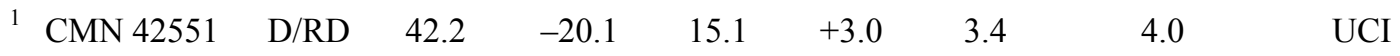

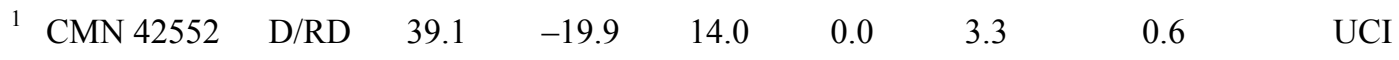

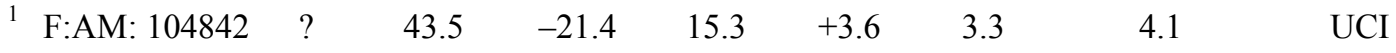

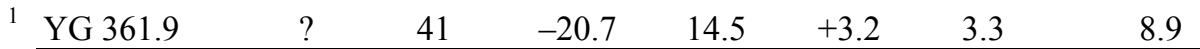

UCI

$\begin{array}{llll}\mathrm{E} & -11.3 & +10.9 & 4.4 \\ \mathrm{E} & -10.6 & +11.4 & 3.7\end{array}$

\begin{tabular}{lcccccccc}
\hline Mean & 42.5 & -20.6 & 15.4 & 4.2 & 3.2 & 10.2 & UCI & -11.1 \\
SD & 42.5 & 0.5 & 0.7 & 1.0 & 0.1 & 6.2 & 4.2 & 0.9 \\
\hline
\end{tabular}

Yukon- Old Crow

Mammuthus 


\begin{tabular}{|c|c|c|c|c|c|c|c|c|c|c|c|c|}
\hline YT1 & $\mathrm{RD}$ & 41.6 & -21.4 & 15.6 & +8.7 & 3.1 & 14.4 & AMS & $\mathrm{E}$ & -11.3 & +11.4 & n.d. \\
\hline YT2 & $\mathrm{RD}$ & 39.2 & -20.9 & 14.6 & +8.4 & 3.1 & 11.0 & AMS & $\mathrm{E}$ & -8.3 & +9.9 & 5.3 \\
\hline YT3 & $\mathrm{D}$ & 44.0 & -21.8 & 16.4 & +9.7 & 3.1 & $>6.7$ & LSIS & $\mathrm{E}$ & -10.1 & +10.0 & 5.5 \\
\hline YT4 & B & 41.1 & -21.4 & 15.2 & +9.5 & 3.1 & 13.1 & AMS & $\mathrm{E}$ & -9.7 & +11.5 & 5.1 \\
\hline YT5 & $\mathrm{RD}$ & 42.9 & -21.5 & 15.5 & +9.8 & 3.2 & 11.2 & LSIS & $\mathrm{E}$ & -8.4 & +10.5 & 5.1 \\
\hline YT6 & $\mathrm{C}$ & 42.5 & -21.7 & 15.2 & +7.7 & 3.3 & 10.1 & LSIS & $\mathrm{E}$ & -9.7 & +9.8 & 4.6 \\
\hline YT7 & B & 42.3 & -21.4 & 15.8 & +7.6 & 3.1 & 15.7 & AMS & $\mathrm{E}$ & -9.1 & +10.2 & 5.3 \\
\hline YT9 & $\mathrm{C}$ & 41.4 & -21.5 & 15.0 & +8.2 & 3.2 & 7.1 & LSIS & $\mathrm{E}$ & -9.9 & +11.9 & 5.0 \\
\hline YT10 & $\mathrm{RD}$ & 38.9 & -21.5 & 14.4 & +9.8 & 3.2 & 11.4 & AMS & $\mathrm{E}$ & -10.9 & +10.7 & 5.3 \\
\hline YT11 & C, RD & 45.6 & -215 & 16.7 & +8.9 & 3.2 & 16.3 & LSIS & $\mathrm{E}$ & -10.6 & +10.5 & 5.1 \\
\hline YT51 & $\mathrm{T}$ & 37.9 & -20.7 & 13.9 & +11.3 & 3.2 & 18.6 & LSIS & & & & \\
\hline Mean & & 41.6 & -21.4 & 15.3 & +9.0 & 3.2 & 12.9 & & & -9.8 & +10.6 & 5.1 \\
\hline SD & & 2.3 & 0.3 & 0.8 & 1.1 & 0.0 & 3.4 & & & 1.0 & 0.7 & 0.3 \\
\hline \multicolumn{13}{|l|}{ Mammut } \\
\hline YT8 & $\mathrm{D}$ & 42.3 & -20.6 & 16.0 & +3.5 & 3.1 & 17.8 & AMS & $\mathrm{E}$ & -11.1 & +11.6 & 4.4 \\
\hline${ }^{1}$ CMN 15352 & $\mathrm{D} / \mathrm{RD}$ & 43.4 & -19.6 & 14.8 & +4.1 & 3.3 & 1.3 & UCI & & & & \\
\hline${ }^{1}$ CMN 31898 & $\mathrm{D} / \mathrm{RD}$ & 42.6 & -19.9 & 15.2 & +2.4 & 3.2 & 2.1 & UCI & & & & \\
\hline \multirow{3}{*}{$\begin{array}{l}1 \text { CMN } 33066 \\
\text { Mean } \\
\text { SD }\end{array}$} & $\mathrm{D} / \mathrm{RD}$ & 43.3 & -20.1 & 15.3 & +2.5 & 3.2 & 3.9 & UCI & & & & \\
\hline & & 42.9 & -20.1 & 15.3 & +3.1 & 3.2 & & & & & & \\
\hline & & 0.5 & 0.4 & 0.5 & 0.8 & 0.1 & & & & & & \\
\hline
\end{tabular}

Yukon- Herschel Island

\begin{tabular}{|c|c|c|c|c|c|c|c|c|c|c|c|c|}
\hline \multicolumn{13}{|c|}{ Proboscidea } \\
\hline YT41 & $\mathrm{T}$ & 45.0 & -22.1 & 16.7 & +10.7 & 3.1 & 17.8 & LSIS & & & & \\
\hline YT42 & $\mathrm{T}$ & 42.7 & -20.3 & 15.7 & +8.2 & 3.2 & 23.3 & AMS & & & & \\
\hline YT43 & $\mathrm{T}$ & 42.5 & -21.9 & 15.5 & +8.0 & 3.2 & 15.1 & LSIS & & & & \\
\hline YT44 & $\mathrm{T}$ & 44.9 & -20.7 & 16.4 & +8.8 & 3.2 & 18.5 & LSIS & & & & \\
\hline YT45 & $\mathrm{T}$ & 43.6 & -21.6 & 16.2 & +15.2 & 3.1 & 21.5 & AMS & & & & \\
\hline Mean & & 43.7 & -21.3 & 16.1 & +10.2 & 3.2 & 19.2 & & & & & \\
\hline SD & & 1.2 & 0.8 & 0.5 & 3.0 & 0.0 & 3.2 & & & & & \\
\hline \multicolumn{13}{|c|}{ Mammuthus } \\
\hline YT39 & $\mathrm{D}$ & 44.4 & -21.7 & 16.2 & 9.7 & 3.2 & 9.0 & LSIS & $\mathrm{E}$ & -13.8 & +12.2 & 5.0 \\
\hline YT40 & $\mathrm{C}$ & 42.4 & -21.5 & 15.9 & +6.8 & 3.1 & 14.1 & AMS & $\mathrm{E}$ & -137 & +13.3 & 5.5 \\
\hline YT46 & $\mathrm{B}$ & 41.7 & -21.6 & 15.5 & +5.5 & 3.1 & 14.8 & LSIS & & & & \\
\hline Mean & & 42.8 & -21.6 & 15.9 & +7.4 & 3.1 & 12.6 & & & -13.7 & +12.7 & 5.2 \\
\hline SD & & 1.4 & 0.1 & 0.3 & 2.2 & 0.0 & 3.2 & & & 0.1 & 0.8 & 0.4 \\
\hline \multicolumn{13}{|l|}{ Mammut } \\
\hline YT38 & B & 41.8 & -21.8 & 15.1 & +5.8 & 3.2 & 13.9 & LSIS & & & & \\
\hline
\end{tabular}




\section{Page 43 of 53}

Journal of Quaternary Science

2

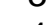
4 5 6 7 8 9 10

11

12

13

14

15

16

17

18

19

20

21

22

23

24

25

26

27

28

29

30

31

32

33

34

35

36

37

38

39

40

41

42

43

44

45

46

47

48

49

Values in bold are the means of duplicate analyses or analyses of different tissues from the same individaul (see Supplementary Table S1).

Tissue: $\mathrm{RD}=$ root dentin, $\mathrm{D}=$ crown dentin, $\mathrm{T}=$ tusk dentin, $\mathrm{B}=$ bone, $\mathrm{C}=$ cementum, $\mathrm{E}=$ enamel

* Lab in which collagen extraction was performed: LSIS (University of Western Ontario), AMS (University of Arizona), UCI (University of California, Irvine)

1 Data are from Zazula et al. (2014). Yields are $>30 \mathrm{kDa}$ fraction of collagen. 
Table 3. Isotopic results for collagen extracted from different areas on AB5 / P90.7.1 (mammoth M6 and M7), in order of inferred development time (top is earliest, bottom is latest).

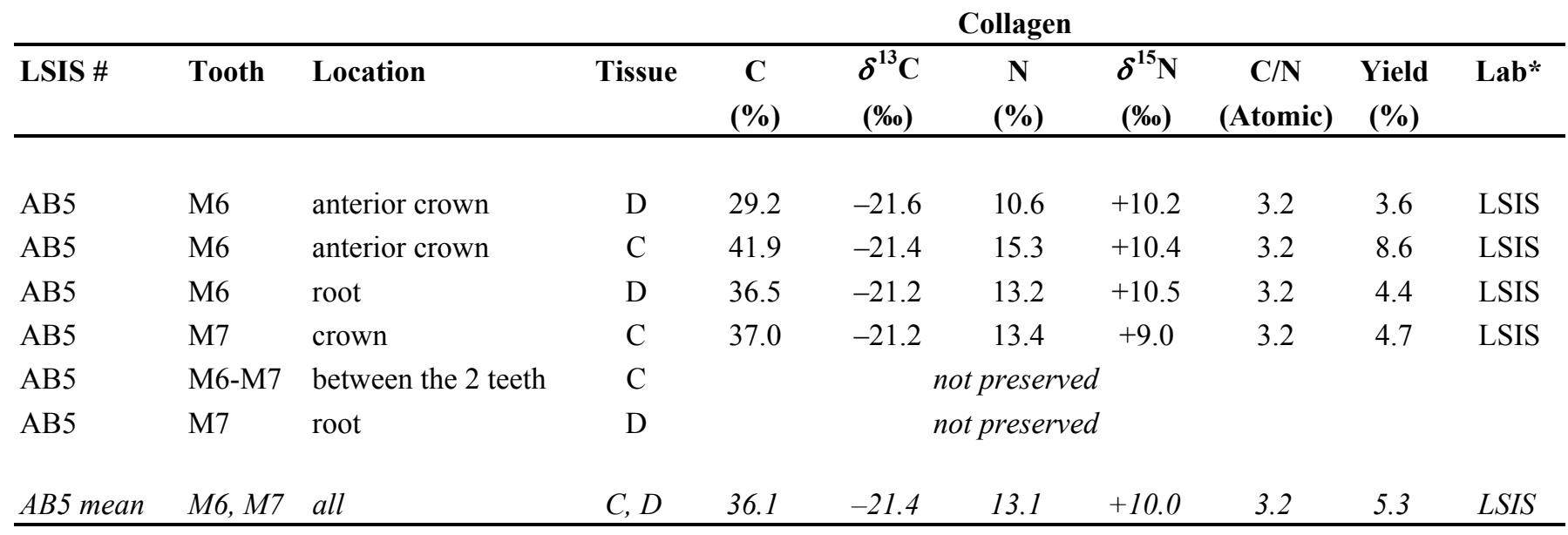

Tissue: $\mathrm{D}=$ dentin, $\mathrm{B}=$ bone, $\mathrm{C}=$ cementum

* Laboratory in which collagen extraction was performed: LSIS (University of Western Ontario) 


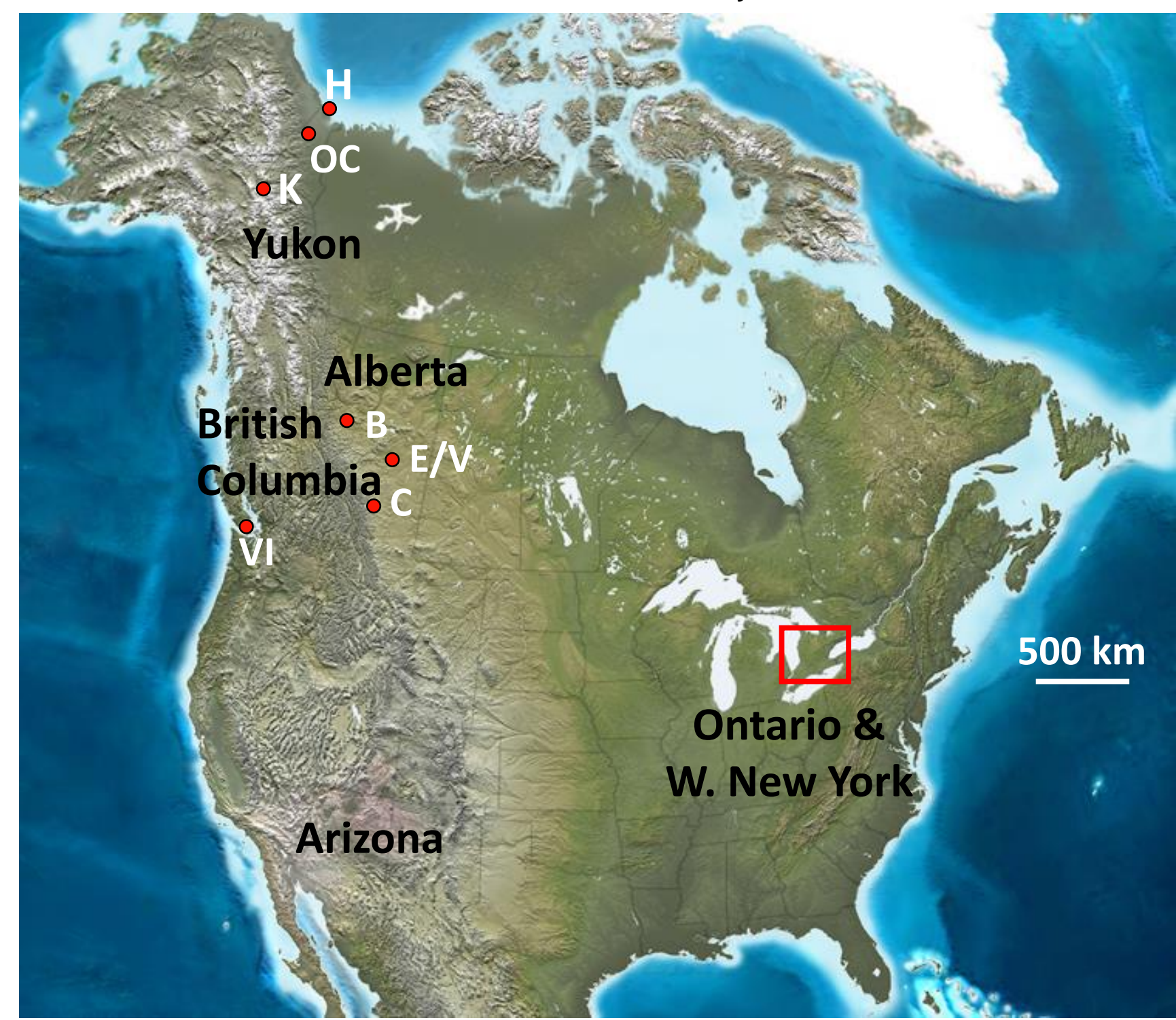




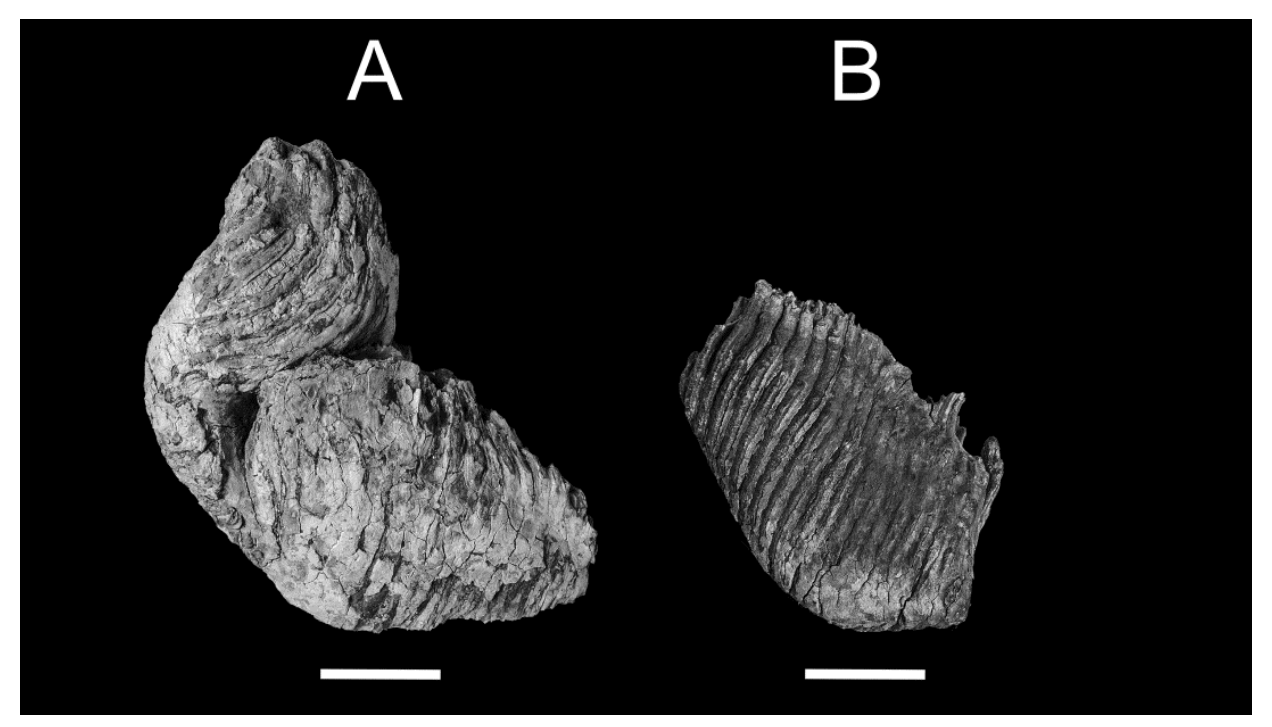

http://mc.manuscriptcentral.com/jqs 


\section{a. Mastodons}

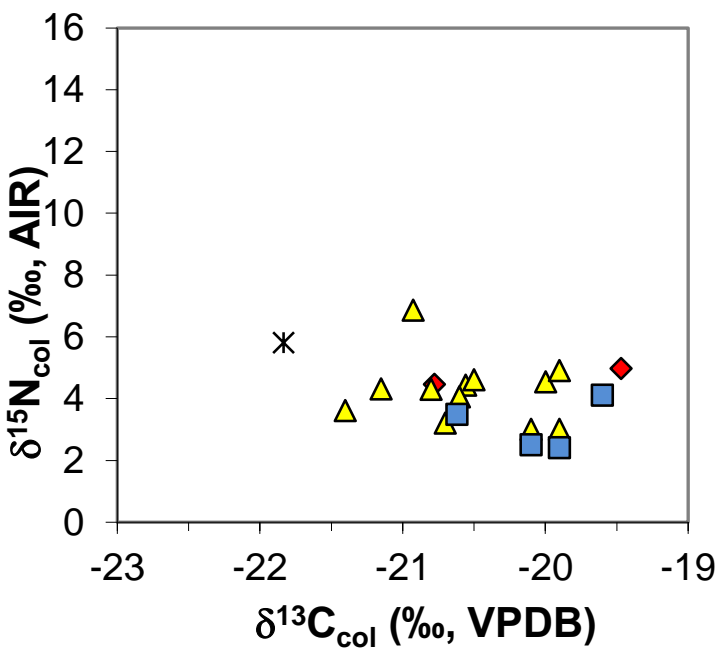

b. Unknown proboscideans

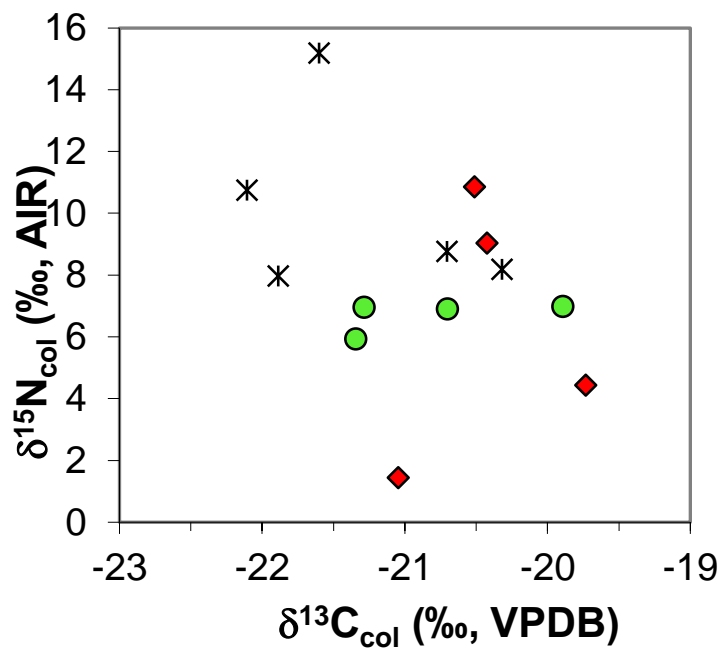

c. Mammoths

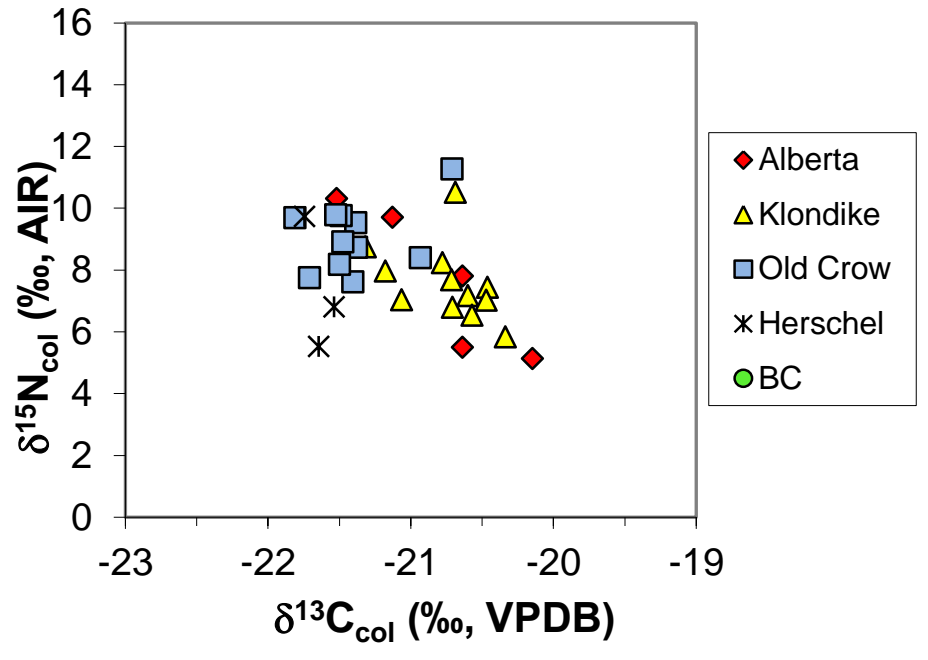




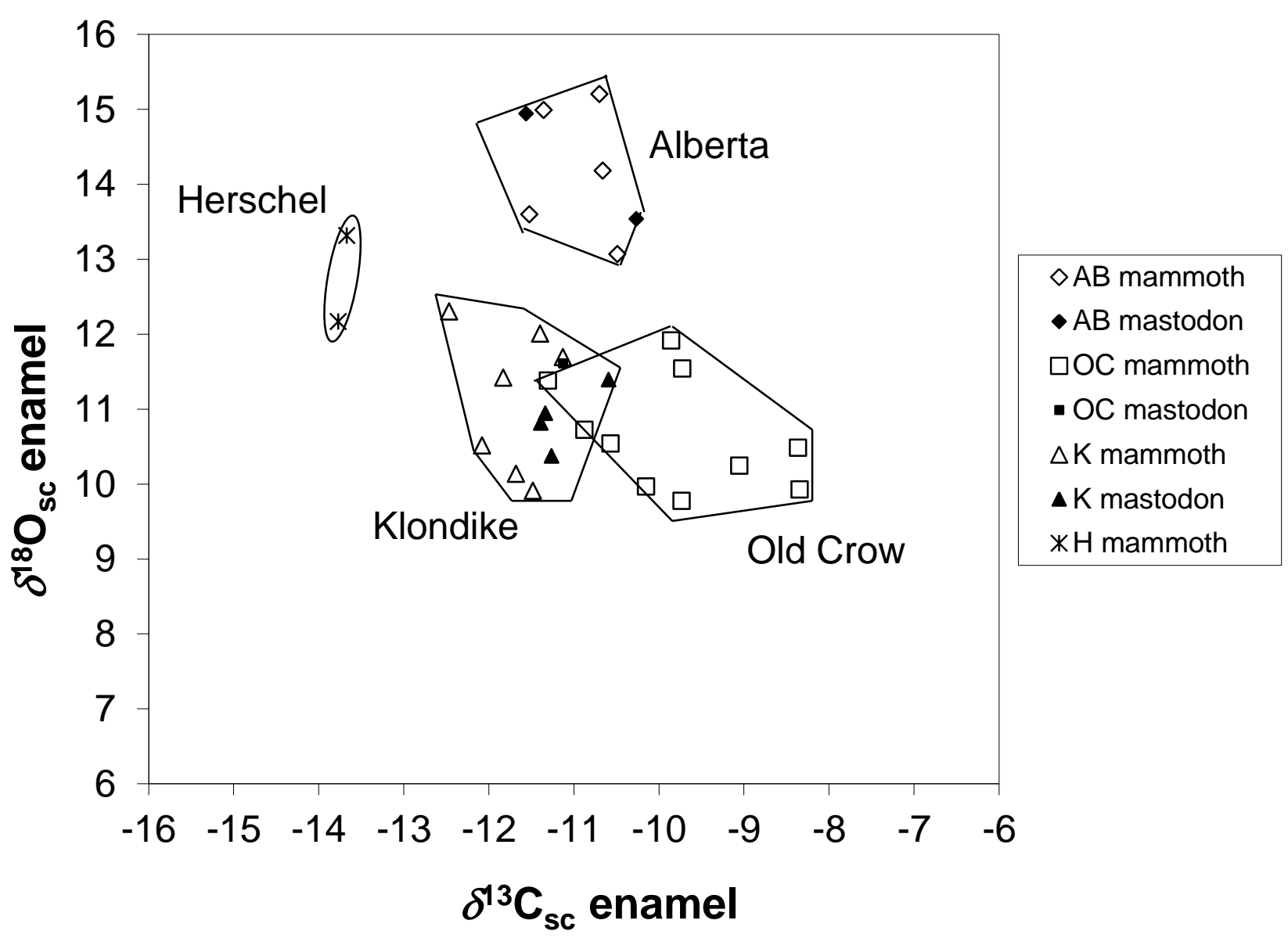

http://mc.manuscriptcentral.com/jqs 
Table S1. Isotopic results for collagen extracted from different tissues within the same individuals (excluding AB5).

\begin{tabular}{|c|c|c|c|c|c|c|c|c|}
\hline \multicolumn{9}{|c|}{ Collagen } \\
\hline LSIS \# & Tissue & $\begin{array}{c}\mathrm{C} \\
(\%) \\
\end{array}$ & $\begin{array}{c}\delta^{13} \mathrm{C} \\
(\%) \\
\end{array}$ & $\begin{array}{c}\mathrm{N} \\
(\%) \\
\end{array}$ & $\begin{array}{c}\delta^{15} \mathrm{~N} \\
(\%)\end{array}$ & $\begin{array}{c}\mathrm{C} / \mathrm{N} \\
\text { (Atomic) }\end{array}$ & $\begin{array}{c}\text { Yield } \\
(\%) \\
\end{array}$ & Lab* \\
\hline $\mathrm{AB} 1$ & B & 44.4 & -20.8 & 16.7 & +7.3 & 3.1 & 16.0 & LSIS \\
\hline $\mathrm{AB} 1$ & $\mathrm{C}$ & 39.7 & -20.6 & 14.9 & +8.0 & 3.1 & $>11.0$ & LSIS \\
\hline AB1 & $\mathrm{D}$ & 38.6 & -20.5 & 15.1 & +8.2 & 3.0 & $>5.9$ & LSIS \\
\hline AB1 mean & $\mathrm{B}, \mathrm{C}, \mathrm{D}$ & 40.9 & -20.6 & 15.6 & +7.8 & 3.1 & $>5.9$ to 16.0 & LSIS \\
\hline $\mathrm{AB} 2$ & $\mathrm{C}$ & 42.1 & -21.1 & 15.6 & +9.9 & 3.1 & 14.4 & AMS \\
\hline $\mathrm{AB} 2$ & $\mathrm{D}$ & 30.1 & -21.1 & 10.9 & +9.5 & 3.2 & $>15.5$ & LSIS \\
\hline AB2 mean & $\mathrm{C}, \mathrm{D}$ & 36.1 & -21.1 & 13.3 & +9.7 & 3.2 & 14.4 to $>15.5$ & AMS\&LSIS \\
\hline AB4 & B & 43.5 & -20.9 & 16.3 & +4.1 & 3.1 & 13.6 & LSIS \\
\hline $\mathrm{AB} 4$ & $\mathrm{D}$ & 37.1 & -20.7 & 13.8 & +4.8 & 3.1 & $>11.9$ & LSIS \\
\hline AB4 mean & $\mathrm{B}, \mathrm{D}$ & 40.3 & -20.8 & 15.0 & +4.5 & 3.1 & $>11.9$ to 13.6 & LSIS \\
\hline AB11 & $\mathrm{C}$ & 43.8 & -20.3 & 16.3 & +5.9 & 3.1 & 16.1 & AMS \\
\hline AB11 & $\mathrm{D}$ & 25.9 & -21.0 & 9.7 & +5.1 & 3.1 & $>4.3$ & LSIS \\
\hline AB11 mean & $\mathrm{C}, \mathrm{D}$ & 34.9 & -20.6 & 13.0 & +5.5 & 3.1 & $>4.3$ to 16.1 & AMS \& LSIS \\
\hline YT 11 & $\mathrm{C}$ & 44.1 & -21.5 & 15.9 & +8.3 & 3.2 & 18.2 & LSIS \\
\hline YT 11 & $\mathrm{RD}$ & 47.2 & -21.5 & 17.6 & +9.5 & 3.1 & 14.3 & LSIS \\
\hline YT 11 mean & $\mathrm{C}, \mathrm{RD}$ & 45.6 & -21.5 & 16.7 & +8.9 & 3.2 & 16.3 & LSIS \\
\hline
\end{tabular}




\section{Appendix S1. Developmental timing of the AB5 (P90.7.1) mammoth M6/M7}

Interpretation of the isotopic results for the AB5 (P90.7.1) mammoth depends in part on knowledge of mammoth tooth development, which is not yet complete. Although growth rates of proboscidean molar crowns and the timing of eruption and wear have been estimated (Dirks et al., 2012; Haynes, 1991; Laws, 1966; Maschenko, 2002; Metcalfe and Longstaffe, 2012; Metcalfe et al., 2010; Uno et al., 2013), we lack complete knowledge of (1) the time required for a full M6 or M7 to develop, (2) the relative timing (i.e., degree of overlap) of the development of these teeth, and (3) the amount of time that elapsed between the development of the M6/M7 and the AB5 (P90.7.1) mammoth's death. These issues are explained more fully below, and inferences about the developmental timing of the AB5 (P90.7.1) specimen are made based on our best estimates for the timing of mammoth tooth development and the age-at-death of the AB5 (P90.7.1) mammoth.

In proboscidean teeth, lamellae (plates) are formed in sequence from anterior to posterior. Anterior crown dentin forms first, followed by anterior enamel and cementum (Hillson, 2005; Maschenko, 2002). Root formation begins after the lamellae of the crown are present, but before the cementum is completely formed (Maschenko, 2002). In general, as one tooth is in wear another is developing posterior to it, but there can be overlap in the development time of successive teeth (Laws, 1966). Growth of mammoth and modern elephant teeth crowns in the occlusal-basal direction occurs at a rate of 13 to $22 \mathrm{~mm} / \mathrm{a}$ (Dirks et al., 2012; Metcalfe and Longstaffe, 2012; Uno et al., 2013). Dirks et al. (2012) estimated that in Mammuthus columbi it took about 10.6 years for an enamel plate of $180.9 \mathrm{~mm}$ height to develop, but this does not necessarily include the full mineralization time, and is an estimate for only one lamella. The full 
development time for a single tooth also depends on the number of lamellae present, the height of each lamella, and the developmental timing of the crown dentin, roots, and cementum, which remains unknown. Since the anterior of an M6 is in wear while the posterior is still developing, it is not possible to physically measure the "full" tooth at any given time. The rate of development of the M7, which may differ from that of the M6, also remains unknown. Based on the general development of proboscidean teeth, we can infer the following relative timing of development for our subsamples: (1) anterior M6 dentin, (2) anterior M6 cementum, (3) M6 root dentin, (4) M7 crown cementum, (5) cementum between the M6 and M7, (6) M7 root dentin. The potential for overlap in the developmental timing of the M6 and M7 is discussed below.

We lack any general knowledge of the developmental timing of M7 relative to that of M6, since the former is not normally present in elephant dentition. Based on the development and wear of elephant and mammoth teeth (Haynes, 1991; Laws, 1966), full crown formation of a Mammuthus M6 likely occurred occur over a period of about 17 years, between ages 26 and 43 (Metcalfe et al., 2010). Burns et al. (2003) estimated the AB5 mammoth to be about 47-48 years old at the time of death. If these inferences are correct, then only about 4-5 years elapsed between complete formation of the M6 crown and the animal's death. Burns et al. (2003:82) infer that the M7 "was undoubtedly deformed from a very early stage of its development because it is so thoroughly distorted... virtually all lamellae were disengaged from their neighbours and later cemented at odd angles." They further argue that "the M6 was fully erupted when the M7 was forced into place, but that the M6 functioned for some years before the M7 came to rest" (Burns et al., 2003:82). Thus, the morphological evidence indicates that deformation of the M7 occurred after formation of the M6 was complete. However, the M7 lamellae may have begun to form either before or after the posterior/basal portions of the M6 were still developing. As 
described in the main text, the isotopic compositions of the teeth can provide additional insight into this problem. Similar isotopic compositions for the two teeth would support the idea that there was significant overlap in their development times, whereas different isotopic compositions would suggest that they developed largely at different times. The latter proved to be the case: different $\delta^{15} \mathrm{~N}_{\text {col }}$ values of the M7 crown cementum and the M6 tissues (including the M6 root, the last part of the M6 to develop) support the hypothesis that the M6 was fully formed when the M7 began to develop. Thus, if all of the above inferences are correct, the isotopic data we obtained for the M7 thus represents some portion of the last 4-5 years of the animal's life, whereas the M6 developed earlier, well in advance of the animal's death. Unfortunately, the M7 root and the cementum linking the two teeth, which likely represented the time closest to death, did not contain well-preserved collagen (see main text). Crown cementum develops after crown enamel and dentin, so the M7 crown cementum isotopic results could still represent a period of time close to death. It is currently not possible to determine whether development of the M7 crown cementum would overlap the period of impaired chewing and acute nutritional stress represented by the secondary wear facet on the M7, which apparently developed over a "relatively short time" (Burns et al., 2003: 83).

\section{References}

Burns, J.A., G., B.C., Mol, D., 2003. An extraordinary woolly mammoth molar from Alberta, Canada. Deinsea, 9: 77-85.

Dirks, W., Bromage, T.G., Agenbroad, L.D., 2012. The duration and rate of molar plate formation in Palaeoloxodon cypriotes and Mammuthus columbi from dental histology. Quaternary International, 255: 79-85.

Haynes, G., 1991. Mammoths, mastodonts, and elephants: biology, behavior, and the fossil record. Cambridge University Press, Cambridge New York, 413 pp.

Hillson, S., 2005. Teeth, Cambridge manuals in archaeology. Cambridge University Press, New York.

Laws, R.M., 1966. Age criteria for the African elephant, Loxodonta a. africana. East African Wildlife Journal, 4: 1-37. 
Maschenko, E., 2002. Individual development, biology and evolution of the woolly mammoth. Cranium, 19(1): 4-120.

Metcalfe, J.Z., Longstaffe, F.J., 2012. Mammoth tooth enamel growth rates inferred from stable isotope analysis and histology. Quaternary Research, 77(3): 424-432.

Metcalfe, J.Z., Longstaffe, F.J., Zazula, G.D., 2010. Nursing, weaning, and tooth development in woolly mammoths from Old Crow, Yukon, Canada: Implications for Pleistocene extinctions. Palaeogeography Palaeoclimatology Palaeoecology, 298: 257-270.

Uno, K.T. et al., 2013. Bomb-curve radiocarbon measurement of recent biologic tissues and applications to wildlife forensics and stable isotope (paleo)ecology. Proceedings of the National Academy of Sciences of the United States of America, 110(29): 11736-11741. 